\title{
GALERÍAS DE «MUJERES ILUSTRES» O EL SINUOSO CAMINO DE LA EXCEPCIÓN A LA NORMA COTIDIANA (SS. XV-XVIII).
}

\author{
por

\begin{abstract}
MÓNICA BOLUfER PERUGa
\end{abstract} \\ Universitat de València
}

RESUMEN: Entre los siglos XV y XVIII, los «catálogos de mujeres ilustres» constituyeron un género ampliamente cultivado en toda Europa. De origen bumanístico y cortesano, estaban ligados al discurso de defensa de la kexcelencia» femenina y vebiculaban valores propios de una sociedad articulada sobre el principio del privilegio y de una ética aristocrática, a la vez que transmitían imágenes femeninas ambivalentes, inquietantes y poderosas. Su pervivencia y éxito en el siglo XVIII, en el que conquistaron nuevos medios, como la prensa periódica, y gozaron de cierta popularidad, plantea interrogantes sobre los significados multiples que para los bombres y mujeres de la época pudieron tener estos modelos disonantes con respecto a los valores ilustrados y las nuevas formas de entender la diferencia de las sexos. El análisis de los usos y formas diversas que este género revistió en la España del siglo XVIII ilustra, pues, sobre las transformaciones en los modelos de feminidad al tiempo que sobre las apropiaciones de las imágenes culturales en un tiempo de cambios.

Palabras ClavE: Mujeres. Cultura. Ilustración. Educación. Erudición.

ABSTRACT: Between the fifteenth and the eighteentb centuries, collections of «illustrious women" were a very widely spread genre all over Europe. Humanistic and courtly in their origins, they were linked to the discourse of women's rexcellence" and they transmitted the values of privilege and aristocratic ethics. At the same time, they sbowed ambivalent, disturbing and powerful images of wwomen on top". The fact that its popularity seems to bave increased during the eighteenth century and that they took more widespread forms such as articles in the periodicals raises interesting questions about the meanings those images, opposed in many ways to Enlightenment values and attitudes, could bave for eighteenth-century men and women. Therefore, an analysis of the different forms and uses of the genre in eighteenth century Spain

Hípania, LX/1, núm. 204 (2000) 181-224 
illustrates the transformations in models of femininity and constitutes an example of cultural appropiation and reshaping of traditional images in a period of change.

KEY WORDS: Women. Culture. Enlightenment. Education. Erudition.

En 1794 vio la luz en España, en una bella edición en 4 volúmenes, una obra francesa publicada casi 150 años antes, la Galería de mujeres fuertes del jesuita francés Pierre Le Moyne. Primorosamente encuadernada e ilustrada con grabados, la versión castellana iba dedicada a la condesa-duquesa de Benavente. Su ilustre destinataria, al leer la obra, encontraría en ella un conjunto de semblanzas de mujeres ilustres de la Antigüedad clásica, bíblica y cristiana. Cada uno de los personajes aparecía representado en un grabado que contrastaba poderosamente con las amables figuras femeninas características de la iconografía contemporánea, en especial de las convenciones de la pintura rococó. Al contrario, miraban al espectador en actitud orgullosa y desafiante, enarbolando en muchas ocasiones armas representativas de su acción heroica, como Débora, provista de casco, espada y escudo, o Juana de Arco, vestida de guerrero al uso del siglo XVII'. La prosa barroca de Le Moyne, traducida por Miguel Pombo y Robledo, se correspondía con esas poderosas imágenes, contrastando a su vez con el contenido y estilo de la escritura neoclásica o prerromántica al uso, en vigorosos retratos literarios como los de Débora y Zenobia:

«Pero ya viene Debora armada y preparada para el combate. Su brazo levantado manifiesta la impaciencia de su zelo, y ya se dexa ver su corazon todo fuego en sus ojos y en su semblante».

«la que veis que caza tan bravamente y con tanto valor, es la famosa Zenobia, Reyna de los Palmiros, que cazó últimamente a las aguilas Romanas; y con la derrota de un exercito imperial, se aseguró la conquista del Egipto. Una caza tan gloriosa y de tan gran trabajo merecia bien que la diversion y el reposo la siguiesen: mas esta generosa muger no ha querido tomar este descanso en su gabinete y á la sombra del dosel, como hacen otras, sino que este mismo descanso es activo y heroyco, y sus diversiones son los combates peligtosos, y los ensayos de las victorias”?2.

Nada más discordante con el modelo de feminidad doméstica que iba tomando cuerpo en el siglo XVIII que estas altivas semblanzas de «mujeres fuertes». Investidas con los atributos del coraje, valentía, prudencia política y sagacidad militar, se oponían diametralmente a la concepción de la diferencia com-

I Un interesante análisis de la iconografía de la «mujer fuerte» en la pintura y el grabado francés del siglo XVII, en MACLEAN, Ian, Woman triumphant. Feminism in French Literature, 1610 1652. Oxford, Clarendon Press, 1977, cap. VII. Utiliza como ejemplos las ilustraciones de François Chaveau para la edición original de La Galerie des femmes fortes (París, 1647).

2 LE MOYNe, Pierre, Galeria de mugeres fuertes. Madrid, Benito Cano, 1794, t. I, p. 31 y II, p. 168.

Hispania, LX/1, núm. 204 (2000) 181-224 
plementaria de los sexos que reservaba a los hombres la fuerza y la plena razón y atribuía a las mujeres una mayor debilidad y sensibilidad. ¿Qué hubiese pensado, por ejemplo, del retrato de la reina Zenobia, intrépida amazona, cazadora y guerrera, Leandro Moratín, quien en las observaciones sobre su viaje a Inglaterra reprobaba con estas palabras a las mujeres que abandonaban la delicadeza y decoro propios de su sexo para adoptar actitudes masculinas?:

«una mujer sobre un caballo no parece bien: cuando su sexo se nos presenta robusto, rígido y feroz, como en este caso, desaparecen la delicadeza y la timidez, que son los signos que le caracterizan. La mujer que gusta de domar caballos, despídase de enamorar corazones: toda acción de fuerza es extraña en ellas, y en tanto son amables, en cuanto nos parecen débiles (...). Sean ellas hermosas, sensibles, tímidas y delicadas; éstas son las armas que la naturaleza les concedió; nosotros, endurecidos en las fatigas, vencedores de las fieras y los elementos, cedamos sólo a unos ojos y a una boca que sonríe suavemente, a cuya violencia deliciosa no hay corazón que no se rinda. Tal es su destino, tal es el nuestro»33.

Así, frente a la marea de la renovación ilustrada en los modelos de feminidad, Jas imágenes heroicas, míticas y poderosas entaizadas en la tradición renacentista y barroca de la "excelencia" femenina aparecen como una roca inmóvil. Resistentes al tiempo y al oleaje cultural, los catálogos de «mujeres ilustres» parecen desafiar con sus colecciones de damas célebres en letras, en gobierno y en armas tanto la hagiografia tradicional de santas y mártires como otra «hagiografia», ésta laica e ilustrada, de madres y esposas modélicas. Con la perduración en el siglo XVIII de los moldes literarios en los que se encarnaba, la figura de la «mujer fuerte» no sólo pervivió, sino que conquistó espacios nuevos, como el de la prensa periódica, ampliando el horizonte de su público. ¿Constituye su fortuna en la época de la Ilustración una simple inercia intelectual, un anacronismo incómodo para el historiador que busca la homogeneidad de las representaciones culturales y trata de documentar su evolución en un solo sentido? ¿O bien encubre esa aparente continuidad formal profundas transformaciones, por las cuales el significado de estas imágenes arcaicas se adaptó a los cambios culturales y sociales?. Las páginas que siguen tratan de dar respuestas a este interrogante.

\section{LAS VICISITUDES DE UNA TRADICIÓN SECULAR.}

La recopilación de vidas de «mujeres ilustres» es un género de antiguos blasones que, con orígenes en la Antigüedad clásica, floreció de forma particular en los siglos XVI-XVIII (Bucci, 1983; Pomata, 1990). Formalmente, solía consistir

3 FERNÁNDEZ De MORATÍn, Leandro, Apuntaciones sueltas de Inglaterra. Madrid, Bruguera, 1984, Pp. 56-57. Sobre los modelos de feminidad ilustrada, véase Bolufer, Mónica, Mujerese e llustración. La construcción de la feminidad en la España del siglo XVIII. Valencia, Alfons el Magnànim, 1998. 
en una monografía o tratado constituido por breves reseñas biográficas de personajes femeninos históricos, bíblicos o míticos, clasificados en unas categorías ya establecidas: mujeres sabias, mujeres heroicas en castidad, en hechos de armas, en "prudencia política" o en el mantenimiento del secreto. Los retratos podían también formar parte de una obra más amplia, pero tanto en uno como en otro caso se inscribían en el contexto de la llamada «querella de las mujeres», es decir, el debate, altamente formalizado, que entre los siglos XV-XVIII enfrentó a defensores y detractores de las mujeres en centenares de obras publicadas en las distintas lenguas europeas. En el transcurso de esa polémica, todos los antagonistas usaron a su modo del recurso a la Historia. Los autores misóginos desgranaban en favor de sus argumentos listas infamantes de mujeres a las que decían culpables de graves perjuicios a la humanidad (encabezadas por Eva y, en el caso español, la Cava), a la vez que minimizaban los méritos de las «mujeres ilustres» señalando que éstos no invalidaban la inferioridad de su $\operatorname{sexo}^{4}$. Pero fueron sobre todo los defensores de las mujeres, que, a diferencia de sus detractores, no contaban apenas con autoridades intelectuales en las que apoyarse entre los Padres de la Iglesia o los filósofos antiguos, quienes recurrieron al pasado, histórico o mítico, para probar las cualidades de las que decían capaces a las mujeres. Aquéllas, precisamente, que el discurso misógino les negaba: sabiduría, castidad, prudencia política, valor guerrero o constancia en el mantenimiento del secreto. La obra de Plutarco Mulierum virtutes, con la que el historiador griego defendió ante Tucídides la conveniencia de honrar públicamente la virtud en ambos sexos, constituyó el primer ejemplo del géneros. Junto con la célebre De mulieribus claris de Boccaccio, traducida al castellano en 1494 y punto de partida de una tradición de biografía laica femenina equivalente a la literatura renacentista de los «hombres ilustres», fue una inagotable fuente de ejemplos para los catálogos medievales y modernos, que tendían a imitarse unos a otros y a repetir de forma estereotipada los mismos retratos. Aun cuando las tendencias racionalistas restaran importancia a los argumentos de autoridad y pretendieran demostrar la igualdad entre los sexos con criterios de evidencia filosófica, como hizo en Francia el cartesiano Poulain de la Barre

4 Un ejemplo tardío de debate sobre el valor de la excepción femenina es la polémica, estudiada por Geneviève Fraisse, sobre el proyecto de ley de un revolucionario francés, Sylvain Maréchal, que a principios del XIX pretendía negar a las mujeres el acceso a la lectura y la escritura. Fraisse resume así las posturas ante la excepción: su negación, su utilización con carácter de prueba y su aceptación subrayando el carácter extraordinario no extrapolable a las discusiones sobre capacidades generales. El propio Maréchal, cuya propuesta de ley descansaba en criterios de conveniencia social más que en la negación de aptitudes, utiliza el argumento histórico para mostrar la incompatibilidad entre saber y virtud en las mujeres, lanzando la acusación de inmoralidad contra algunos de los personajes clásicos en las obras de apología. Fraisse, Géneviève, Musa de la razón. La demacracia excluyente y la igualdad de lo sexos. Madrid, Cátedra, 1991, pp. 35 y 60-66.

s POMATA, Gianna, «Storia particolare e storia generale. In margine ad alcuni manuali di scoria delle donne», Quaderni Storici, 74 (1990), pp. 341-385 (cica, p. 346). Parte de esta obra de Plutarco se tradujo al castellano a finales del XVIII en el Correa de los Ciegos; vid. infra. 
(De l'égalité des deux sexes, 1687) o en nuestro país el P. Feijoo ( Defensa de las mujeres", disc. XVI del t. I del Teatro crítico, 1726), Ios hechos heroicos de las mujeres del pasado siguieron formando parte del bagaje dialéctico en las posteriores manifestaciones del debate sobre la diferencia de los sexos.

La amplia tradición de los catálogos europeos de «mujeres ilustres» fue conocida y utilizada por los autores españoles que en el siglo XVIII ensalzaron sus méritos, bien en tratados monográficos o en obras de contenido más amplio $^{6}$. «Esta clase de obras las hay en todos los idiomas», indicaba en 1790 Josefa Amar, en su Discurso sobre la educación física y moral de las mujeres para excusarse de ofrecer ejemplos históricos del mérito de las mujeres. En lugar de ello, remitió a sus lectores a una serie de tratados entre los que figuraban el de Thomas Essai sur lesprit, les moeurs et le caractère des femmes dans les différents siècles (1772, traducido al castellano en 1773) y algunos clásicos del género como Le glorie inmortali dei trionfi ed beroiche imprese d'ottocento quarantacinque donne illustri (1609) de Paolo Ribera, Les Eloges et les vies des reines et princesses et des dames illustres de Hilarion de la Coste y, quizá, Les femmes illustres ou les barangues héroüques de Madeleine de Scudéry (1642), al que Josefa Amar pudo haber aludido bajo la vaga referencia de "Mugeres ilustres". Otros autores españoles que en el siglo recopilaron ejemplos de "mujeres célebres" conocían, asimismo, las obras italianas, francesas, holandesas o castellanas de Boccaccio, Plutarco, Capaccio, Christine de Pisan, Lucrezia Marinelli, Anna Maria Schurmann o Martín Carrillo, mientras que a su vez, las listas de retratos elaboradas por Feijoo o Cubié se convirtieron en fuente de la que se nutrirían numerosas obras posteriores.

Entroncados con esa tradición europea, aparecieron en España a lo largo del siglo XVIII diversos catálogos de «mujeres célebres», entre ellos Las mugeres vindicadas (1768) de Cubié, las Memorias de las Reynas Catholicas de Flórez (1761) o las Memorias de las mugeres ilustres de España (1798) de Alonso Álvarez, primer tomo de lo que se proyectaba como una magna recopilación de damas de todos los tiempos, pero que no llegó a pasar de los primeros siglos cristianos $^{7}$. Estas fueron algunas de las obras con las que los eruditos españoles pre-

6 Sobre las obras de este género escritas en diversas lenguas en los siglos XV-XVIlI, véanse: ALBISTUR, Maïté; ARMOGathe, Daniel, Histoire du féminisme français. París, Éditions des fernmes, 1977; ANGENOT, Marc, Les champions des femmes. Le discours sur la superiorite feminine, 1400-1800. Montréal, Presses Universitaires du Québec, 1977; BROWNE, Alice, The Eighteenth Century Feminist Mind. Brighton, The Harvester Press, 1987; BuCcl, Susanna, «La produzione letteraria dedicata alle donne illustri. Pubblico e autori nel clima polenico del dibattito sui diritti del sesso femminile», en TARICCONE, Fiorenza; BUCCI, Susanna: La condizione della donna nel XVII e XVII secolo. Roma, Carucci, 1983; MACLEAN, Op. cit.; GefFrIAUD-Rosso, Jeanette, Études sur la féminité an XVIle-XVIIIe siècles. Pisa, Goliardica, 1983; RANG, Brita, «A ulearned wave». Women of letters and science from the Renaissance to the Enlightenment», en AKKERman, Tjitske, y StuURman, Siep, eds., Perspettives on Feminist Political Thougbt in European History. From the Middle Ages to the Present. LondresNueva York, Rourledge, 1998, pp. 50.66.

? CuBIÉ, Juan Bautista, Las mugeres vindicadas de las calumnias de los bombres, con un catálogo de las Españolas que más se ban distinguido en Ciencias y Armas. Madrid, Antonio Pérez de Soto, 1768 . LE 
tendieron «inmortalizar su nombre» escribiendo «las Memorias de las Mugeres ilustres de sus naciones», tal como afirmaba la supuesta «dama» a quien Alonso Álvarez atribuía el ánimo para publicar su libro, y en cuya boca ponía esta alabanza de los méritos de su sexo:

«Nosotras hemos tenido parte en las revoluciones mas famosas del mundo. Nuestras alianzas han dado muchas veces la paz ó la guerra a las provincias. No solamente los hombres, tambien las mugeres supieron empuñar el Cetro, y gobernar con acierto en la menor edad de sus hijos. Muchas siguieron á Marte; muchas á Minerva, y superiores á la debilidad de su sexo, fueron la gloria y el honor de su siglon (Álvarez, 1798, XIII).

Asimismo, otros catálogos de mujeres ilustres escritos por autores extranjeros circulaton con notable éxito entre el público español. La Galería de mugeres fuertes de Le Moyne, con la que hemos abierto estas páginas, fue traducida tardíamente en 1794, mientras que Las Mugeres ilustres o arengas beroycas de Madeleine de Scudéry (publicada en 1642 bajo el nombre de su hermano) apareció por entregas entre 1796 y 1798, aunque no se conocen ejemplares de esta edición ni han quedado más testimonios de ella que los anuncios aparecidos en la Gaceta de Madrid, dando puntual noticia de la aparición de los sucesivos folletos $^{8}$. Por otra parte, las relaciones de mujeres célebres continuaron formando parte de los argumentos desplegados en la querella de los sexos, y en calidad de tales figuraron en la "Defensa de las mujeres» de Feijoo y en la encendida polémica a que ésta dio lugar, así como, ya en la segunda mitad del siglo, en las obras escritas en defensa de las mujeres por Thomas, Pueyo de San Pedro (una imitación del anterior), Josefa Amar, Vicente del Seixo, o en una publicación periódica como El Hablador juicioso $0^{9}$. Secciones dedicadas a las mujeres de letras

MOYNE, Op. cit. ÁlVAREZ, Antonio, Memorias de las mugeres ilustres de Evpaña, t.l (fue el único publicado). Madrid, Sancha, 1798. Flórez, Enrique, Memorias de las Reynas Catholicas, Historia Genealogica de la Casa Real de Castilla, y de León. Madrid, Antonio Marín, 1761.

a Existe edición moderna: SCUDERY, Madeleine, Les femmes illustres ou les barangues béroïques (1642). París, Côté-femmes, 1989. La obra se tradujo atribuyéndola a «Mr. Escudery» (el hermano de la escritora). La edición de los sucesivos opúsculos fue dada a conocer por la Gaceta de Madrid, $\mathrm{n}$. 3 (9-I-1796, 36), 9 (19-I-1796, 88), 36 (3-V-1796, 388), 52 (28-VI-1796, 540), 70 (30-VIII$1796,720), 79(30-1 X-1796,816)$ y $86(26-X-1798,924)$. Este último texto saludaba la aparición de la obra completa en 2 tomos. Al anunciarse la segunda entrega los diaristas reproducian la siguiente explicación, que sin duda pretendia aguijonear el interés de los lectores pero que, de ser cierta, avalaría el éxito de la obra: «El reconocimiento del editor a la benignidad con que el público recibió los dos anteriores lo empeña a publicar estas con mas proncirud de lo que pensaba».

9 THOMAS, Antoine-Léonard, Historia o pintura del talento, carácter y costumbres de las mugeres Madrid, Miguel Escribano, 1773. PUEYO DE SAN PEDRO, José, Discurso bistorico i pbilosópbico sobre el carácter, costumbres $i$ mérito de las mugeres. Manuscrito de I805. BN, Ms. 4445. AMAR, Josefa, «Discurso en defensa del talenco de las mujeres..." (1786), en NEGRín FAJARDO, Olegario, La educación popular en España en la segunda mitad del siglo XVIII. Madrid, UNED, 1984, pp. 162-176. SEIXO, Vicente, Discurso filosbfico y económico-politico sobre la capacidad o incapacidad natural de las mugeres para 
antiguas y modernas del pasado aparecieron también en recopilaciones eruditas - apologéticas de la literatura española, como la Bibliotheca Hispana Nova de Nicolás Antonio (reeditada en 1788), que recogía en su apéndice "Gynaeceum Hispanae Minervae» información sobre 51 autoras españolas, o el Ensayo apologético del abate Lampillas, o bien circularon en el formato de diccionario tan caro a la literatura divulgativa dieciochesca ${ }^{10}$.

No obstante, la vitalidad del género se manifestó sobre todo en su conquista de un nuevo medio: la prensa. Del mismo modo que las entregas periódicas, al precio de 2 reales cada una, de las Mugeres ilustres de Madeleine de Scudéry pudieron seguramente llegar a un mayor número de lectores que la obra ya encuadernada, anunciada por la Gaceta al precio de 20 y 17 reales los dos tomos, las series de retratos insertas en las publicaciones periódicas debieron tener un mayor alcance social que los lujosos volúmenes de la Galería de mujeres fuertes de Le Moyne dedicados a la condesa-duquesa de Benavente. La primera publicación literaria por entregas que se conoce en España, los Varios discursos eloquentes y políticos de Nifo, incluyó en sus pequeños folletos retratos de personajes femeninos con reminiscencias barrocas ${ }^{11}$. Con posterioridad, aparecieron también en algunos periódicos, desgranadas a lo largo de semanas o meses de publicación, breves biografias de damas ilustres extraídas del amplio repertorio de catálogos, desde Plutarco a Thomas, pasando por Feijoo o Boccaccio. El Correo de los Ciegos incluyó, a partir de su número 344 (13-III-1790) y a lo largo de 24 entregas, fragmentos de las «Mujeres ilustres» de Plutarco, vanagloriándose de que se trataba de la primera versión directa al castellano y afirmando su objetivo de probar que ese una misma la virtud de los hombres que de las

las Ciencias y las Artes....Madrid, 1801. El Hablador juicioso, traducción anónima (atribuida a Francisco Mariano Nifo) del periódico publicado por el abate Langlet. Madrid, Francisco Xavier García, 1763.

10 ANTONIO, Nicolás, Bibliotheca Hispana Nova. Madrid, viuda y herederos de Ibarra, 1788. LAMPILLAS, Xavier, Ensayo bistbrico-apologético de la literatura española. 2." edición, corregida, enmendada e ilustrada con notas por la traductora, Josefa Amar. Madrid, Pedro Marín, 1789. Ladvocar, Jean Baptiste, Diccionario bistorico abreviado que contiene la bistoria de los Patriarcbas, principes bebreos, emperadores, reyes $i$ grandes capitanes, de los papas, obispos, bistoriadores, poetas, gramáticos, de las mugeres sabias, de todas Personas ilustres, ofamosas de los Siglos, $i$ Naciones del Mundo. Traducido al español por Don Agustín Ibarra. Madrid, Joseph Rico, 1753-54.

1 Nifo, Francisco Mariano, Varios discursos eloquentes y politicos sobre las acciones más beroitas de diferentes personajes antiguas y modernos. Madrid, Gabriel Ramírez, 1755. Según AGULAR PIǸAL, Francisco, Bibliografía de escritores españoles del siglo XVII. Madrid, CSIC, 1981-1999, (V, ref. 446) se trata de textos traducidos del italiano. Su publicación se suspendió con el número 9 . Entre los que hemos consultado interesan el Assunto primero. Faustina, bija del grande Marco Antonio Pio, y emperatriz de Roma, reprebendida por su esposo Marco Aurelio, con sentencias politicas y elegantes, en las que se ofrece una perfecta idea de la modestia, bonestidad y decoro, vasas fimes, que sossienen con magestad y bermosura la grande y pradigiosa máquina de La sociedad bumana, y el Assunto segundo. Isicratea, reyna del Panto y espasa de Mitridates, ofrece a todo el nespetable gremio de las señoras mugeres la más deconosa imagen de la fidelidad conjugal, intentando generosa, varonil, noble y amante ir á sufrir las incomodidades de la Guerra con su consorte. 
mugeres»12. En las páginas del Diario de Valencia se publicó entre 1791 y 1792 una sección titulada «La Tertulia de Doña Leonor», en la que las «damas" participantes extractaban, basándose en las obras de Feijoo y de Thomas, los méritos de las mujeres, desde las griegas o romanas a las literatas francesas o españolas de la historia reciente ${ }^{13}$. Años más tarde, entre 1797 y 1798, esa misma publicación ofreció una larga galería de retratos que alternaba figuras femeninas y masculinas, antiguas y modernas ${ }^{14}$. Por su parte, el Correo literario de Murcia publicó en 1794, a lo largo de 30 números, una serie similar, aunque limitada a personajes bíblicos y clásicos ${ }^{15}$. Así pues, a finales de siglo la compilación de biografías de "mujeres célebres" parecía ser un elemento habitual en los contenidos de la prensa periódica que aspiraba a alcanzar a un público amplio, cultivado y con afanes de distinción, aunque no necesariamente sabio o erudito.

Si los catálogos se adaptaron con tal fortuna a la prensa fue gracias a sus características particulares. Su estructura de breves rasgos biográficos resultaba apropiada para la publicación periódica, pues se adaptaba al formato reducido de la prensa y permitía desgranar con regularidad, a lo largo de semanas o meses, un rosario de personajes históricos. Podemos pensar que, enmarcándose en el género divulgativo de los "papeles periódicos», los retratos de mujeres ilustres satisfacían el interés de un público amplio y diverso por la Historia, en la que se buscaba con preferencia el ejemplo moral o la anécdota llamativa. Así, además de adoctrinar a los lectores, las "hazañas» de las mujeres sabias, teinas o guerreras pudieron satisfacer su avidez por asomarse a un pasado heroico y

12 «Mugeres ilustres de Plutarco, traducido del griego por Don Juan Pons Izquierdo». La relación de méritos, individuales (los de Arria, Lucrecia, Valeria, Clelia, Camma, Aretafila) y colectivos («las Quías», «las de Argos", "las Celtas»...), se prolonga, a razón de un extracto en cada número, hasta el n. ${ }^{\circ} 367$ del t. VII.

13 Las supuesta concertulias abordan los méritos de las mujeres griegas (Diario de Valencia, en adelante D.V. n. ${ }^{\circ} 111,19-\mathrm{IX}-1791,74-75$ ), las kvalientes y esforzadas Romanas" (D.V. n. ${ }^{\circ} 118$, 26-X-1791, 101-103), «la prudencia de las Mugeres» (D.V. n. ${ }^{0}$ 125, 2-XI-1791, 130-131), «las Mugeres valerosas" (n. ${ }^{\circ} 131,8-X I-1791,154-155$ ), «las Mugeres Christianas" (n. ${ }^{\circ} 139,16-X I-$ $1791,186-187$ ), las heroicas en hechos de armas (n. ${ }^{\circ} 146,23-X I-1791,213-215$ ), las sabias antiguas (n. ${ }^{\circ} 160,7-X I I-1791,270-272$ ), españolas e italianas (n. ${ }^{\circ} 167,14-X I I-1791,298-299$ ), francesas e inglesas ( $\mathbf{n}^{\circ}$ 181, 28-XII-1791, 354-355). Sobre estos y otros ejemplos de escritura y tertulias femeninas en la prensa, véase BOLUFER, Mónica, «Espectadores y lectores: representaciones e influencia del público femenino en la prensa del siglo XVIII, Cuademos de Estudios del siglo XVII, n. ${ }^{\circ}$ 5 (1995), pp. 23-57.

14 Dido, Artemisa, Sitri Maani, Zenobia, Isicratea, Amalasunta se contaron entre las mujeres «antiguas» y Luisa Sigea, Mme. de Lambert, Mme. Dacier, Sor Juana Inés de la Cruz, Marie de Gournay, Catalina de Aragón, María Estuardo, Casandra Fidele, Isotta Nogarola, Sor Juana Morella, la valenciana Angela Zabata, entre las «modernas», que hasta un número de $\mathbf{4 2}$ aparecieron con periodicidad semanal, alternando con otros tantos hombres ilustres, a lo largo de los tomos XXIX al XXXII (julio de 1797 a junio de 1798) del D.V.

15 La serie se inicia con una "Carta sobre la traducción de los hechos de las mugeres sabias" (Correo literario de Murcia, n. ${ }^{\circ} 187,14-\mathrm{VI}-1794$ ) a la que siguen, hasta el $\mathrm{n} .^{\circ} 208,7$ reseñas de personajes ilustres.

Hispania, LX/1, núm. 204 (2000) 181-224 
mítico, muy diferente de sus vivencias cotidianas, colmando así un interés por lo inusual y maravilloso, y aun por lo morboso, que las publicaciones periódicas pretendían contentar con sus anécdotas de hechos «extraordinarios" en campos variados, desde los «prodigios" naturales a las acciones sorprendentes $o$ atroces: inundaciones y catástrofes, partos múltiples y monstruos animales o humanos.

Los perfiles que de estas figuras dibujan sus apologistas sesultan machaconamente repetitivos. En efecto, nada más monótono que estas estampas literarias que reitetan, siglo tras siglo, los mismos ejemplos clásicos y, en menor medida, bíblicos, medievales o modernos en las categorías de "excelencia» codificadas por una larga tradición europea que sus autores mostraban conocer bien $^{16}$. Personajes como Lucrecia, Porcia y Aspasia, Safo y Theano, Amalasunta e Isicratea, Judit o Débora, Juana de Arco, Isabel la Católica o Luisa Sigea pueblan las páginas de infinitos catálogos. Muchos retratos venían transmitiéndose a través de los catálogos durante siglos y otros se incorporaron con el tiempo, sin variar la estructura de las enumeraciones ${ }^{17}$. Cada una de las virtudes ensalzadas se encarnaba en unos rostros habituales, se tratase del valor militar (sobre el cual era usual evocar las figuras de Zenobia, Juana de Arco, Blanca de Rossi, Bonna de la Valtelina, María Estrada o las mujeres que habían resistido asedios turcos), de la castidad y el amor conyugal (ejemplificados por Lucrecia, Pantea o Porcia), la prudencia en el gobierno (exhibida por Débora o Semíramis tanto como por Isabel la Católica o María de Médicis) o la sabiduría (representada por mujeres como Oliva Sabuco de Nantes o Isotta Nogarola). Erigidas en prueba intemporal de una virtud, estas figuras aparecían tepresentadas con un carácter «icónico», según advierte Gianna Pomata $(1990,347)$, configurando, en palabras de M. ${ }^{\mathrm{a}}$ Victoria López-Cordón, "personajes de un solo trazo" $(1994,83)^{18}$. Quedaban abstraídas de su contexto hasta el punto de que en una misma sección del Diario de Valencia, por ejemplo, célebres suicidas romanas alternan con sabias francesas del siglo XVIII. Excepción a este respecto la constituye el ensayo histórico de Alonso Alvarez, que relaciona las transformaciones en los méritos de las mujeres ilustres (de la época de las «guerreras» a la de las «sabias» o las «santas») con la evolución política y cultural de la

16 Véanse como ejemplo las referencias a otras obras contenidas en CuBrÉ, Op, cit., pp. 77-138; NIFO, Op. cit., sin paginar; ANTONIO, Op. cit., p. 343. THOMAS, Op. cit., pP. 98-112 ofreció una larga lista de catálogos de los siglos XVI y XVII, que Pueyo de San Pedro y el D.V. reprodujeron parcialmente (D. V. n. ${ }^{\circ} 12,12-1-1792,42-43$ y n. ${ }^{\circ} 18,18-\mathrm{I}-1792,70-71$ ).

17 Tanto en obras del siglo XVIII como en otras anteriores, de las que pueden ser ejemplos la española de MOYA, Juan, Varia Historia de Sanctas e illustres Mugeres en todo género de virtudes. Madrid, Francisco Sánchez, 1583, o las de AGRIPPA DE NETTESHEIM, Cornelio, De la noblesse et préexcellence du sexe féminin (1529). París, Côté-femrnes, 1990; Marrnelli, Lucrezia, La nobilità e leccelenza delle donne co' difetti e mancamenti degli uomini. Venecia, Ciotti, 1601; GOURNAY, Marie de, Égalité des bommes et des femmes (1622). Paris, Côté-femmes, 1989, y ScuDÉRY, Op. cit., los mismos ejemplos se repiten constantemente.

18 LÓPEZ-CORDÓN, M." Victoria, «La conceptualización de las mujeres en el Antiguo Régimen: los arquetipos sexistas», Manuscrits, 12 (1994), pp. 79-107. 
España antigua. Como también y particularmente la obra de Thomas, auténtica histoire des moeurs al gusto ilustrado que tomaba el estado de las costumbres y la relación entre los sexos como indicador del progreso o corrupción de las sociedades, o la de su imitador español Pueyo de San Pedro, quien se proponía examinar «hasta qué punto el gobierno, las circunstancias y las leyes pueden elevarlas, i las relaciones secretas de la polytica con sus costumbres", "qué han sido las mugeres en varios siglos i cómo ha podido influir en su carácter el espíritu común de su tiempon ${ }^{19}$. Lo usual es, por el contrario, que en los retratos que integran estas "galerías" literarias el contexto se difumine o desaparezca, del mismo modo que en los grabados que ilustran la obra de Le Moyne el fondo aparece lejano e impreciso, resaltando las envaradas figuras de las «mujeres fuertes".

No obstante, pese a su carácter estereotipado y su aparente inmovilismo, los catálogos de «mujeres ilustres» no permanecieron absolutamente invariables a lo largo de los siglos. En cierta medida, cada época seleccionaba los personajes de «mujeres célebres» de acuerdo con un particular sistema de valores. Así, por ejemplo, en Italia, según ha constatado Ilaria Porciani, el belicoso siglo XVII se inclinó por rendir homenaje a las mujeres guerreras, mientras que el XIX, el siglo de la unificación, se interesó por ensalzar a las madres y esposas de héroes nacionales ${ }^{20}$. Del mismo modo, el apogeo de la figura de la «femme forte» en la literatura y la iconografía francesa desde mediados del siglo XVII tendría que ver, a juicio de Ian MacLean, con la preeminencia de que gozaban las mujeres nobles en los círculos cortesanos, culturales, religiosos y políticos durante la regencia de María de Médicis y el reinado de Luis XIII (MacLean, 1977, 76-77). Cierto es que resulta engañoso interpretar sin más las virtudes reseñadas por los recopiladores de biografias como indicativas de los valores que pretendian inculcar a las mujeres de su época, pues muchas de las obras en las que aparecieron eran traducciones tardías de tratados del siglo anterior, y unas y otras bebían sin recato en las fuentes de antiguos catálogos. Pese a ello, los orgullosos perfiles de las mujeres ilustres muestran huellas de los cambios acaecidos en las sociedades que produjeron esa secular tradición. En su origen fueron emblemas de una sociedad estamental, y su carácter aristocrático se hacía patente tanto en la condición social de las destinatarias de las obras como en los valores que los retratos ensalzaban. En efecto, los catálogos de mujeres ilustres en la España del siglo XVIII continuaron la tradición de las apologías renacentistas y barrocas del mérito de las mujeres, que solían ir dedicadas a damas de la realeza o la aristocracia (por ejemplo, el humanista Cornelio Agrippa de Nettesheim dedicó su Discours sur la noblesse et l'excellence du sexe féminin, publicado en 1529 en latín y en 1530 en francés, a la princesa Margarita

\footnotetext{
19 Pueyo de SAN Pedro, Op. cit., fol $13 \mathrm{v}$.

20 PORCIAN], Ilaria, «Il Plutarco femminile», en SOLDANI, Simonetta, ed., L'educazione delle donne. Scuole e modelli di vita femminile nell Italia dell Ottocento. Milano, Franco Angeli, 1989, pp. 297-317.
} 
de Austria). Alonso Ruiz de Piña, traductor de Thomas, dedicó su versión de 1773 a la duquesa viuda de Pópoli, mientras que Cubié ofreció su obra de 1768 a la condesa de las Amayuelas. El traductor de Le Moyne se acogió a la protección de la condesa-duquesa de Benavente, manifestando seguir en ello la voluntad del autor, que había deseado que en sucesivas versiones de la obra tras su muerte «se pusiera al frente de la obra una Heroina que llevase su nombre, la diese autoridad, y estuviese adornada de virtud, discrecion, fortaleza y espíritu». El tono hiperbólico propio de las dedicatorias se utilizaba para hacer de las damas elogiadas continuadoras de las mujeres ilustres del pasado; así, Nifo aduló a la duquesa viuda de Arcos, al obsequiarla con el segundo de sus Varios discursos eloquentes y políticos, afirmando que «el noble heroysmo de Isicratea, fue como profecía de la naturaleza, en que quiso representar muy de antemano lo que habiamos de ver nosotros en nuestro tiempo, y ofrecer una idea, figura, retrato o symbolo de V. Excelencia en la bizarra hidalguia de esta Reyna». De ese modo, evocando a las "mujeres célebres", los autores rendían el tributo debido a sus mecenas y a los nobles linajes que éstas representaban.

El origen aristocrático de las relaciones de mujeres ilustres se pone de relieve también en la condición social de la mayor parte de las protagonistas, habitualmente reinas, princesas o damas de elevado rango. Pero sobre todo, se manifiesta en la glosa de sus méritos, que no representaban tanto las cualidades deseables en la mujer como encarnaban en figuras femeninas los valores propios del estamento privilegiado y compartidos por la sociedad de Antiguo Régimen. Letras, armas y gobierno son, junto a la castidad, los ejes que centran la alabanza de las mujeres «excelentes». Un perfil que resulta mucho más próximo a la imagen nobiliaria y cortesana del métito, cifrado en el prestigio de las armas (como reminiscencia del ejercicio militar de la antigua nobleza guerrera) y en las dotes para el gobierno o para el cultivo de las letras (como marcas de su función cortesana), que al concepto burgués de virtud como honestidad, autocontrol y laboriosidad en su versión masculina o castidad, sensibilidad y pureza en la femenina. Estos elogios vehiculaban una idea de virtud laica, que destaca el mérito personal y rehuye hacer de la gracia divina el motor de la acción heroica, "porque hazañas donde intervino especial auxilio soberano acreditan el poder divino, no la facultad natural del sexo ${ }^{21}$. Aunque en algunos textos, como los de Álvarez o Le Moyne, la santidad militante ocupa un lugar más destacado, los perfiles de las mártires cristianas y los de las heroínas paganas apenas se distinguen, y tanto unas como otras destacan por su determinación y arrojo ${ }^{22}$. De ese modo, la acepción que de la «mujer fuerte» ofrecen

${ }^{21}$ FEIjoO, Benito Jerónimo, Teatro crítico universal de errores comunes. Madrid, Herederos de Francisco del Hierto, 1742 ( $7 .^{\mathrm{a}}$ ed.), t. I, disc. XVI, p. 346.

22 Le Moyne escalona sus elogios distinguiendo cuatro categorías entre las amujeres fuertes»: las «fuertes judías», «bárbaras», «romanas» y «cristianas». Por su parte, Álvarez diferencia tres épocas en la Historia antigua de España, asignando a cada una de ellas un zipo de mérito femenino, cada uno superior al anterior: hasta la época del emperador Cayo, las mujeres paganas heroicas en 
estas obras se aleja de la virtud sumisa y doméstica que encarnaba la "mujer fuerte» del capítulo 31 de los Proverbios, cita obligada en todos los tratados morales de conducta femenina. Se asemeja más bien a la «virtus» clásica y renacentista, la "fortitudo" que se cifra en la magnanimidad, constancia, energía y resolución e inviste de un carácter activo incluso la más convencional cualidad de la castidad (MacLean, 1977, 82-84).

En su calidad de evocación admirativa de una acción excepcional, los retratos de mujeres ilustres cuadraban con la lógica de una sociedad del privilegio, regida por el particularismo jurídico y por la creencia en la desigualdad natural de las personas, mientras que se avendrían menos con las sociedades nacidas de las revoluciones liberales e inspiradas por el principio de igualdad teórica de los individuos ${ }^{23}$. Las «mujeres fuertes» encarnan en su lejanía del común de los mortales la intrínseca superioridad natural con que la nobleza se representaba a sí misma y gustaba de ser contemplada. Representan esa inaccesibilidad de forma mucho más clara a como podían hacerlo los hombres célebres, porque, a diferencia de ellos, se retrataban como seres capaces de «superar», según gustaban de decir los apologistas, los límites de su sexo. Su excepcionalidad con respecto a las demás mujeres no consistía, pues, sólo en llevar a su extremo más heroico las virtudes que les eran comunes, como sería el caso de los héroes masculinos en relación al resto de los hombres, sino en poseer en grado sumo, según se decía, las cualidades propias del otro sexo. Así, su posición excepcional respecto de los límites de género actuaba al mismo tiempo como metáfora de otras desigualdades sociales, las que establecían una diferencia necesaria y vinculada al nacimiento entre las personas del común y los estamentos privilegiados.

Transportada al campo de la propaganda política, esa imagen de superioridad con respecto al resto de los mortales sirvió como apoyo retórico para la justificación de la monarquía absoluta. Así lo ejemplifica el elogio de la reina M. ${ }^{a}$ Luisa de Parma que la marquesa viuda de Sonora pronunció en 1796, en representación de la Junta de Damas de Honor y Mérito, en la entrega anual de premios de la Sociedad Económica Matritense. En ese texto de circunstancias, publicado luego, como era habitual, en una cuidada edición de Ibarra, la marquesa optó, a diferencia de sus antecesoras en ese encargo, por ofrecer de la soberana una imagen distinta de aquella de corte ilustrado y doméstico que trazaría en 1798 la marquesa de Fuerte Híjar, quien presentó a la soberana como una «esposa tierna», en cuyo regazo podía el rey «depositar sus cuidados», y «madre oficiosa», tanto de sus hijos como de sus súbditos ${ }^{24}$. Por el contrario, la marquesa de Sonora no repitió los elogios de ese estilo que a la reina

hechos de armas, antes de la llegada del cristianismo las mujeres cultas, y finalmente las santas y márcires.

23 Véase al respecto FraISSE, Op. cit., pp. 13 y 203.

${ }_{24}$ Ríos, M. ${ }^{2}$ Lorenza de los (marquesa de Fuerte Híjar), Elogio de la Reyna N. S. formado por la Señora Marquesa de Fuerte Hijar, letdo en Junta pública general de distribución de Premios que celebró la Real Sociedad Eronónica de Madrid en 15 de Septiembre de 1798. Madrid, Sancha, [1798]. 
habían prodigado otras damas de la Junta. Y declinó hacerlo con el argumento de que, si bien para encomiar a una señora bastaba con glosar sus virtudes comunes al sexo, las alabanzas a una soberana «deben componerse de acciones conocidamente grandes y sublimes por su naturalezan ${ }^{25}$. Se esforzó, por tanto, en probar que el heroísmo, al contrario de lo que solía pensarse y de lo que la educación al uso propiciaba, era una virtud que podían poseer las mujeres, «porque si las costumbres modernas dispensan al bello sexo (no sé por qué desgracia) la falta de heroísmo, la historia nos recuerda que la naturaleza no les ha rehusado estos dones, de que comunmente las despoja una educación mal dirigida". Esa fortaleza y grandeza del alma, inspiradora de grandes cosas, de nobles sentimientos, que caracterizaba «a los Héroes de ambos sexos», era «la gran virtud que hace Señor de sí mismo al que la posee, abriéndole de esta manera el camino de la justa dominacion, y excelencia sobre el resto de los hombres: es la virtud propia de un Soberano". Aunque el particular «heroísmo» que atribuyó la marquesa de Sonora a $\mathbf{M}^{2}{ }^{\text {L Luisa de Parma no consistía en }}$ hechos de armas sino en una constancia de ánimo o serenidad ante el infortunio, el lenguaje (propio de la tradición de "mujeres fuertes») utilizado para ensalzarlo contrastaba con el tono sentimental en el que la marquesa de Fuerte Híjar hizo la semblanza de las virtudes domésticas de la soberana. Vistos en su conjunto, la serie de elogios de la reina que las damas de la Junta se turnaton para escribir con motivo de la ceremonia anual de entrega de premios de la Sociedad Económica ofrecían un retrato con dos caras. Un contraste que las propias autoras buscaron de forma deliberada, puesto que en sus presentaciones explicaban siempre que darían de la reina un perfil que completase el proporcionado por las anteriores autoras. En las palabras laudatorias y en buena medida convencionales de estos escritos de circunstancias se perfilan dos imágenes distintas de la monarquía, una más propia de la tealeza tradicional y otra acorde con los perfiles paternalistas (en este caso, «maternales») del absolutismo ilustrado, encarnadas en dos modelos diferentes de feminidad: el vigoroso y «viril» de las «mujeres célebres» y el sentimental de la reina como madre afectuosa y responsable de sus súbditos. Mujer heroica, representada al estilo de las efigies de las reinas del pasado, pero también madre ejemplar, como se les exigía a las mujeres de su tiempo, la imagen pública de $\mathbf{M}^{2}{ }^{2}$ Luisa de Parma se ofrecía así a la vez inasequible y próxima, distante y familiar.

También las figuras de las protagonistas de los Varios discursos eloquentes traducidos por Nifo en 1755, mujeres de noble linaje como la emperatriz romana Faustina o Isicratea, reina del Ponto, transmitían un doble mensaje que tiene una lectura social compleja. Por una parte, enseñaban que el egregio nacimiento no eximía a las mujeres de abrazar una moral intachable: «No creas, que por ser Emperatriz, y por haberte ensalzado este Solio al auge de la grandeza, que

25 VAlenzuela, M. ${ }^{2}$ Josefa (marquesa de Sonora), Elogio de la Reyna N. S., Leído por la Marquesa de Sonora, vixda, en La Junta pública de 17 de marzo de 1796 de la Sociedad Económica de Madrid. Madrid, Sancha, [1796],p. 3.

Hispania, LX/1, núm. 204 (2000) 181-224 
por esto estas exempta de observar las leyes de la honestidad» -advierte Mitrídates a su esposa Isicratea. Pero al mismo tiempo, mostraban, a través de ejemplos como el de Isicratea, capaz de superar la «debilidad del sexo", que su status privilegiado las elevaba a una condición de «excelencia» por encima de las mujeres comunes. Así, más que un ejemplo de conducta moral para la imitación, el prodigioso control sobre sus pasiones que exhibía este personaje parece una metáfora del privilegio asociado a su rango y un ejemplo de la excepcionalidad por la que se admitía que algunas mujeres superasen las limitaciones de su sexo:

"Nací Reyna, y por la grandeza de mi principio debo vencer las debiles cobardias de $m i$ sexo (...). Son abortos frequentes de la ley de sus obligaciones aquellas mugeres que, por abusar del privilegio de su sexo, se eximen de perder la vida en defensa del marido (...) Dos veces me considero Reyna, una haciendome amar, y temer de los subditos, y otra sujetando la inquieta rebeldia de mis afectos; porque con la virtud me desvío del mal, con el dominio avassallo el deseo, con las leyes procuro domar las passiones, con el entendimiento aparto á la voluntad del apetito, con la autoridad defiendo el honor, y con la prudencia puedo desayrar las torpes inspiraciones de la malicia (...) Nact muger, que en sentir de todos quiere decir fragilidad; pero si no bay regla, que no admita sus excepciones, quiero por esta regla ser excepcion de las mugeres» (Nifo, 1755, «Assunto segundo», sin paginar).

En este retrato de una soberana de la Antigüedad se muestra, como lo hacía, con matices distintos, en el elogio de la reina M. ${ }^{2}$ Luisa de Parma, la lógica de la excepción, que considera a la «mujer ilustre" un caso particular y unusual, a admirar más que a imitar. La «excelencia» de estas mujeres se hace consistir en la excepcionalidad de sus méritos, desplegados en campos considerados «viriles» por naturaleza, y se relaciona con la posición ocupada por ambas, en tanto que reinas, en la cima de las jerarquías sociales. Todo ello remite, según hemos indicado, a la lógica particularista de una sociedad estamental en la que las cualidades e inclinaciones morales y las normas de conducta se concebían diferenciadas y jerárquicamente graduadas entre los sexos y los estamentos. Cabe por ello preguntarse por qué este género de catálogos de "mujeres ilustres», de raigambre aristocrática y cortesana, gozó de fortuna no sólo en el siglo XVIII sino también en el XIX, en contraste cada vez más abierto con los modelos femeninos entonces representados en textos normativos y literatura de ficción y con el florecimiento de la moral natural que pretendía apoyar los preceptos de conducta sobre la base de sentimientos y obligaciones comunes a los humanos ${ }^{26}$.

26 En efecto, la prensa femenina de! siglo XIX siguió publicando con regularidad semblanzas de mujeres ilustres en esa tradición. Por ejemplo, el Periódico de Las Damas (1822) ofreció una larga serie de retratos de mujeres ilustres, algunas de las cuales corresponden a un pasado reciente (Mme. de Staël, la emperatciz Josefina, Catalina la Grande) pero otros constituyen clásicos en los catálogos de los siglos anteriores: mujeres sabias, castas o guerreras de la Antigüedad (Clelia, Artemisa, Lu- 
A primera vista, la continuidad de estos patrones de representación de la «mujer ilustre» parece reflejar simplemente la inercia de una tradición, erigiéndose en una prueba más de que la cultura del siglo XVIII y sus manifestaciones impresas no pueden identificarse sin más con la Ilustración. Sin embargo, bajo su aparente inmovilismo formal el género se actualizó, adaptándose a las transformaciones de los tiempos. Los catálogos fueron sensibles, en primer lugar, a la mayor presencia de mujeres en los ámbitos de la sociabilidad cultural del siglo XVIII, tanto en España y en Europa, una realidad que debió inspirar el interés por establecer tradiciones retrospectivas, incorporando a las mujeres de letras del presente al panteón de las sabias del pasado. Así, por ejemplo, tanto Vicente del Seixo como el abate Lampillas remataron sus listas de mujeres célebres mencionando a algunas de sus contemporáneas, aunque para el segundo los ejemplos coetáneos desmereciesen un tanto de los de otros tiempos dorados: "Aunque considero el presente siglo muy distante de los principios en que se formaron aquellos grandes modelos, con todo presentaré algunos exemplares no menos dignos de gloria» (Seixo, 1801, 128). También Cubié incluyó entre sus ejemplos (un total de 89 , Ia inmensa mayoría tomados de los siglos XVI y XVII) la referencia a tres mujeres del XVIII: Catalina Caso (traductora de Rollin), Mariana Alderete y M. ${ }^{a}$ Rosario Cepeda, mientras que Pueyo de San Pedro comparó a las socias de la Junta de Damas con las heroínas de las que existía constancia en la Historia.

Los catálogos acusaron también el crecimiento del número de lectoras, parte de un proceso general de ampliación y diversificación del público lector por el cual los escritores en el siglo XVIII se hicieron cada vez menos dependientes del mecenazgo y protección de las grandes familias y más del mercado del libro. Buscando la favorable aceptación del público, muchas obras impresas, entre ellas los propios catálogos de "mujeres célebres», sustituyeron la tradicional dedicatoria a personajes de alta alcurnia por la referencia más amplia y anónima a las lectoras. Así sucede con la apostilla, no sabemos si escrita por el mismo traductor de la obra o por los críticos literarios de la Gaceta de Madrid, que calificaba a Las mugeres ilustres de Mlle. de Scudéry de «obra dedicada a las damas", con el Discurso filosófico y económico-político que Seixo dirigió «a las Señoras mugeres" o con el prólogo de Alonso Álvarez a sus Memorias de las mugeres ilustres de España, en forma de un «Razonamiento de una Dama á un Erudito del siglo XVIII sobre la necesidad de escribir las memorias de las Heroinas de España" que justificaba su obra como si fuese respuesta a la demanda de una «lectora» imaginaria, culta y bien informada, capaz de citar a Feijoo y a Fló-

crecia, Aspasia), de la Edad Media y los primeros siglos modernos (Juana de Arco, Sta. Teresa de Jesús, Inés de Castro...). Asimismo, El Defensor del Bello Sexo (1845-46) ofreció, aunque con menor continuidad, retrazos de este tipo. Véase SIMÓN PALMER, M. ${ }^{a}$ Carmen, «Revistas españolas femeninas del siglo XIX ${ }_{\star}$, en Homenaje a D. Aguttin Millares Carlo. Gran Canaria, Caja Insular de Ahorros, 1975 , I, pp. 401-445 (referencias en pp. 408-411 y 420). 
rez $^{27}$. Asimismo, al traducir la voluminosa obra de Lampillas en defensa de la literatura española, Josefa Amar llamó la atención de las lectoras sobre el elogio de damas ilustres en letras que contenía uno de sus tomos:

«también las mugetes tenemos algún interés en la publicación de esta obra, porque en el tomo IV se hace memoria de algunas Españolas ilustres en las letras. Por esta razon pudiera pretender el agrado entre las de mi sexo, y conseguido el de ambos, no hay mas que apetecer ${ }^{28}$.

A este público crecientemente considerado por los editores, la literatura de mujeres ilustres podía ofrecerle una evasión fugaz. «Para lo que falta en la realidad se busca sustituto en los sueños, en los libros, en los cuadros», afirmó Norbert Elias (1987, 459) para interpretar el auge de la literatura caballeresca, a comienzos de la época moderna, entre una nobleza que, abandonando sus antiguos hábitos guerreros, había comenzado su proceso de domesticación en la Corte $^{29}$. También las lectoras y lectores del siglo XVIII necesitaban soñar. Quizá por ello, la difusión del modelo ilustrado de mujer doméstica parece haber ido acompañada de la permanencia y éxito de modelos «arcaicos» de virtud femenina cuyos comportamientos, diferentes e incluso opuestos a la norma, proporcionasen una válvula imaginaria de escape a la estrechez de las conductas permitidas. De ese modo, las relaciones de mujeres ilustres en la España del siglo XVIII parecen situarse en un momento de transición. Median entre un género que fue aristocrático, en sus destinatarios y su contenido, a lo largo de sus primetos siglos de historia, y los catálogos producidos y consumidos por la sociedad burguesa del siglo XIX, transformados tanto en sus ejemplos y en los valores que ensalzaban como en el público al que se dirigían. Los catálogos españoles del siglo XVIII no reelaboraban radicalmente la tradición, como lo haría, por ejemplo, en la centuria siguiente la literatura de «mujeres ejemplares» de la Italia unificada. Ésta, alejándose de las orgullosas relaciones anteriores de «mujeres célebres", participó del proceso por el cual la burguesía inventó una tradición patriótica, bien en su versión conservadora (exaltando a las madres heroicas y mujeres caritativas y devotas) o en la liberal (loando a las italianas meritorias en moral o en Letras), según ha estudiado Ilaria Porciani (1989). Sin llegar a tal extremo, las obras de ese género, originales y traducidas, que se publicaron en España en el siglo XVIII, sobre todo en sus últimos decenios, parecen contemporizar entre elementos de innovación y otros de permanencia. Su autores se enfrentaban con la paradoja de ofrecer a lectores y lectoras de su tiempo ejemplos extraídos de la historia reciente mezclados con otros que tení-

27 Gaceta de Madrid, n. 3 (9-1-1796, 36).

28 Amar, prólogo sin paginar a LAMPILLAS, Op. cit., t. I.

29 ELIAS, Norbert, El proceso de civilización. Investigaciones sociogenéticas y psicogenéticas. México, FCE, 1987, p. 459. Sobre los códigos de conducta cortesanos ver también del mismo autor La sociedad cortesana. México, FCE, 1982. 
an sabor anacrónico, no tanto por su lejanía histórica como por el contraste entre los méritos ensalzados en las arrojadas reinas, guerreras y sabias de la tradición y otras cualidades, las de discreción, ternura, sensibilidad y domesticidad, propias de la nueva representación de las mujeres en el siglo XVIII. El resultado fue una mezcla de tradición y novedad que desplegaba la habilidad característica del género para reunir en sus páginas figuras heterogéneas y que se dirigía a un público heterogéneo. Por una parte, las dedicatorias a damas de la nobleza traducían, además de la pleitesía debida al mecenazgo, la idea de que ellas constituían las destinatarias «naturales» de un discurso sobre la «excelencia» femenina que encarnaba en mujeres excepcionales una apología de las virtudes aristocráticas. Pero al mismo tiempo, los autores eran conscientes de que debían contar con un público más variado y común de mujeres y hombres cuyas vidas poco tenían que ver con las virtudes exaltadas por las galerías de «mujeres célebres».

La clave para la pervivencia y vitalidad del género de mujeres ilustres parece cifrarse, así, en su carácter de instrumento dúctil y abierto a interpretaciones diferentes, que le permitía adaptarse tanto a los cambios sociales como a las diversas intenciones de sus autores. $\mathrm{Al}$ incorporar nuevas figuras al panteón de celebridades, al modelar de diversos modos la cantera de ejemplos codificados por la tradición o añadir comentarios que destacaban, oscurecían o censuraban ciertos aspectos de los personajes para acomodarlos al mensaje que se pretendía extraer de ellos, los autores del siglo XVIII transformaron sutilmente un género en apariencia estereotipado. $A$ su vez, del autor original al traductor que realizaba la versión castellana, en ocasiones con más de un siglo de distancia, y de éstos a los lectores y lectoras del siglo XVIII se tiende una compleja trayectotia interpretativa que apenas podemos intuir. Unos y otros trataban de sugerir lecturas codificadas de los textos al público de su tiempo, quien a su vez extraería de las obras impresiones no del todo coincidentes con las intenciones de aquéllos.

A través de estos procedimientos, los usos tradicionales que hacían del catálogo de mujeres ilustres bien un argumento en favor de la superioridad o igualdad femenina, bien una oportunidad para digresiones morales, es decir, el "Catálogo-prueba" o el "catálogo-pretexto», tal como los denomina Bucci $(1983,152)$, se vieron ampliados en el siglo XVIII con otras funciones. Las figuras de damas sabias formaron parte de la literatura apologética en defensa del "mérito literario de España» o de los actos de homenaje a jóvenes nobles por sus talentos intelectuales, configurando lo que, excusando el anacronismo y con cierta dosis de ironía, quizá podríamos llamar el "catálogo-escaparate». En coyunturas bélicas, se desplegaron, si se quiere a modo de "catálogo-bandera», las anécdotas de mujeres heroicas que buscaban promover el enardecimiento patriótico. Así, durante la guerra de la Convención el anecdotario de la contienda, pero también la historia antigua, reinterpretada, nutrieton las páginas de la prensa de ejemplos de coraje, como el «Episodio del cerco de Salamanca 
por Aníbal, en recuerdo de las valerosas mugeres y para dar ánimo en los tiempos presentes", oportunamente publicado por el Semanario de Salamanca en 1795 ( $.^{\circ} 138,10$ enero 1795$)$. Un ejemplo más de las formas en que el elogio de las «mujeres ilustres» del pasado se adaptaba a las mudables circunstancias del presente.

\section{LOS USOS DEL CATÁLOGO. EL VALOR DE LA EXCEPCIÓN.}

En su origen y a lo largo de los siglos, los catálogos de «mujeres célebres» se utilizaron como prueba en favor de la capacidad de las mujeres. Por ello las semblanzas tendían a organizarse en categorías fijas, correspondientes a las "cualidades» que les atribuían sus defensores y negaban sus enemigos en el contexto de la "querella de las mujeres» o debate sobre las capacidades morales e intelectuales de los sexos. La mezcla anacrónica de ejemplos legados por la tradición más remota (clásicos, bíblicos, míticos) y de otros incorporados por el género a lo largo de su historia se explica por esa misma razón. Para discutir algo que se presumía tan invariable como la "naturaleza» de las mujeres, el mismo valor probatorio parecía ofrecer la evocación de las sabias griegas y romanas, las valientes amazonas (sobre cuya existencia se debatió en el siglo XVIII), las heroínas de las luchas contra los turcos o las mujeres de letras del pasado reciente ${ }^{30}$. Todas ellas, de Hypatia a Catalina la Grande, de Porcia a Juana de Arco, se traían a colación igualmente para demostrar que la «naturaleza» había hecho a las mujeres castas y valientes, prudentes y dotadas para la sabiduría. Y así lo sostuvieron, polemizando de manera implícito o expresa con

30 Sobre el mito de las amazonas, la fascinación que suscitó a to largo de los siglos y las nuevas defensas de su existencia en el siglo XVIII, ver CONTI ODORISIO, Ginevta, Donna e società nell Seicento. Lucrezia Marinelli e Ariangela Tirabotti. Roma, Bulzoni Editore, 1979, pp. 71-73; Darmon, Pierre, Mythologie de la femme en France sous l'Ancien Régime. París, Seuil, 1983, pp. 145ss; Davis, Natalie, «Un mundo al revés: las mujeres en el poder», en AMELANG, James; NASH, Mary, eds.: Historia y género. Las mujeres en la Europa moderna y contemporánea. Valencia, Edicions Alfons el Magnànim, 1990, pp. 59-92. Poulain de la Barre nombró a este mítico pueblo de rujeres belicosas en dos ocasiones en su obra De l'égalité des deux sexes, aunque sin manifestar certeza sobre su existencia real. Feijoo se mostró también cauto al respecto, aunque inclinado a creer en ella: "Algunos Autores niegan su existencia, contra muchos mas que la afirman. Lo que podernos conceder es, que se ha mezclado en la Historia de las Amazonas mucho de Fabula (...). Pero no puede negarse sin temeridad, contra la fe de tantos escritores antiguos, que huvo un cuerpo formidable de mugeres belicosas en la Asia, á quienes se dió el nombre de Amazonas. Y en caso que tambien esto se niegue: por las Amazonas que nos quitan en la Asia, para gloria de las mugeres, parecerán Amazonas en las otras tres partes del Mundo, America, Africa y Europa». (Fejoo, Op. cit., pp. 350-351). Frente a las críticas de Mañer, Sarmiento defendió a Feijoo precisanda que éste utilizaba el término de amazonas en el sentido de mujeres guerreras que hubieran existido en todo tiempo y lugar, $y$ aportando textos de viajeros que hablaban de ellas (SARmiento, Martín, Demostración Crízico-Apologética del Teatro Critico. Madrid, Domingo Fernández Arrojo, 1757, epígrafes VII-X). 
las posturas misóginas, todos los autores de catálogos de damas ilustres, como Josefa Amar, que extrajo de los ejemplos esta conclusión tajante: "no hay prenda que no sea común a entrambos sexos», o la "D. ${ }^{a}$ Leonor» del Diario de Valencia, quien afirmó que la intención de su serie de retratos era «lograr dexen de mirar á nuestro sexo con desprecio en los asuntos politicos y actos del entendimiento, como si la misma mano que repartió los talentos, los hubiese cohartado á solos los hombres» (D.V. n. $\left.{ }^{0} 125,2-X I-1791,130\right)^{31}$.

Evocar las poderosas figuras de mujeres guerreras, reinas y sabias, aun cuando fuera haciendo un mero alarde de erudición o una convencional defensa de las capacidades femeninas, podía ser interpretado como una amenaza para los cimientos del orden social. Así, al menos, lo entendió el «autor» de una curiosa respuesta a las semblanzas de mujeres ilustres publicadas en el Diario de Valencia. El remitente, que firmó con el significativo pseudónimo (a buen seguro inventado por los editores) de «D. Pacífico Mansueto, Alborotado de Furias", decía temer que las lectoras se identificasen con los ejemplos míticos de heroínas y sabias. En su opinión, conjurar los fantasmas de esos personajes heroicos suponía abrir la puerta a un vendaval destructivo del orden social, pues proporcionaba a las mujeres corrientes un estímulo para abandonar las ocupaciones y actitudes domésticas que les eran propias. Su experiencia personal, afirmaba este supuesto «lector», le había hecho dolorosamente palpable tal efecto turbador:

\begin{abstract}
«¿Habrá paciencia para ver como mi muger, hijas y doncellas se están todo el dia, mano sobre mano, apropiandose nombres, que ni por sueños se hallan en los Almanaques, sin acordarse del que me pusieron en el Bautismo, sino para pedirme Diarios? ¿Cómo ha de haber sufrimiento para que mi hija sea Julia, mi cuñada Porcia, mi suegra Artemisa, mi parienta Hortensia, y mi criada Amalasunta? iA Quién no le han de hacer falta los estrivos quando vea que su casa lo es de Orates, que el gato duerme á pierna tendida sobre el hornillo, y que no se advierte en toda ella sombra de rueca, visos de lumbres y olfato de olla? (...) Si de esta suerte andamos, los hombres tendremos que ir desnudos, flacos y macilentos por el mundo, porque todas querrán ser Heroinas. Tendremos que retiramos en los rincones de nuestras casas, dexar los estrados, vaciar los púlpitos, desamparar las varandillas, desertar de las banderas, y renunciar á los cargos públicos, para que las Señoras lo ocupen todo" (D.V. n. ${ }^{\circ} 85,21-$ III-1791, 318-319; cursiva nuestra).
\end{abstract}

El hecho de que "D. ${ }^{2}$ Leonor" y sus contertulias no lanzasen, al ofrecer su relación de méritos femeninos, mensajes de rebeldía no suscitaba suficiente confianza en este lector imaginario. Temía que las poderosas figuras míticas de

${ }_{31}$ Por su parte, Le Moyne dedicó diversas secciones de su obra a interrogarse (y a responder por lo general afirmativamente) sobre esi las mugeres son capaces de la alta generosidad" (III, 109120), de la filosofía (III, 195-208) y de las «virtudes milizares» (II, 185ss). Ver también FElJOO, Op. cit., p. 391; CuBrE, Op. cit., p. 23. 
mujeres «ilustres» cobrasen vida en las mujeres de su tiempo, enfebrecidas, como Don Quijote por las novelas de caballería, con la lectura del Diario, y que (como le sucediera al personaje cervantino) esos ejemplos remotos o irreales perturbaran, con la fuerza de su atracción sobre los comportamientos de las mujeres reales, el recto equilibrio de las cosas. Frente al titilar de un espejismo que temía convertido en la peor de las pesadillas (la de la inversión de los espacios y las atribuciones de los sexos), su carta subrayaba las inalterables prescripciones de la naturaleza reiterando los tópicos misóginos, y pretendía devolver los gigantes a su condición de molinos, es decir, minimizar el valor de las figuras heroicas, insistiendo en su excepcionalidad: «si en las historias se halla alguna heroina digna de los fastos, debemos atribuir sus hazañas á un buen efecto de la temeridad, ó a un destello del acaso, ó en fin a la general adulacion de los hombres, nacida de una reprehensible accion» (D.V. n. ${ }^{\circ} 85$, 21-III-1791, p. 319).

A todas luces, este personaje indignado no era sino una ficción puesta en escena por los mismos editores del Diario de Valencia que habian inventado a "D. ${ }^{a}$ Leonor" y sus compañeras, recurso habitual en la prensa del siglo XVIII. No obstante, la expresión de sus agravios resulta significativa de la faceta turbadora e incómoda que tenía la clásica y respetable galería de mujeres ilustres. Como si cuidasen de evitar en sus lectores reacciones similares o en sus lectoras afanes de emulación, los autores de catálogos procuraron disipar sospechas sobre la rectitud de sus intenciones, mostrando casi invariablemente su conformidad con el orden vigente que excluía a las mujeres de los cargos políticos, la guerra, las Ciencias y Artes o la predicación religiosa. De la capacidad de las mujeres, patente a través de la Historia, para desenvolverse en armas, letras o política, a la viabilidad o conveniencia social de tal desempeño, el margen era amplio, y esa distancia no debía franquearse. Ese es el mensaje que reiteraban la mayoría de los compiladores de «mujeres célebres». "No embidiéis a los hombres el brillante honor de sus marciales triunfos», aconsejó el abate Langlet, autor de El Hablador juicioso, a sus lectoras, tras reconocer que la Historia era concluyente en favor de las mujeres; a su juicio, la gloria y el poder femeninos debían seguir caminos más ocultos e indirectos ${ }^{32}$.

Aunque tampoco Pierre Le Moyne, en su Galería de mugeres fuertes, pretendiese en modo alguno azuzar rebeldías, sus dudas a la hora de atribuir las desigualdades entre los sexos a los usos adquiridos o bien a una naturaleza invariable son significativas de las ambigüedades que contenía el discurso sobre la "excelencia» femenina expresado en la alabanza de las «mujeres célebres». Consciente de las consecuencias subversivas que podían extraerse de su defensa de la capacidad de las mujeres en letras y armas, añadió a su galería de ejemplos históricos reflexiones que trataban de tranquilizar a los lectores. Sin embargo, las mismas vacilaciones de su lenguaje dejaban flotando en el aire una

${ }^{32}$ Langlet: "Carta a las Señoras nueva defensa de su sexo", El Hablador Juicioso, n. ${ }^{\circ}$ 2, pp. 3-20 y n. ${ }^{\circ} 3$, pp. $23 \cdot 36$; cita p. 19.

Hispania, LX/1, núm. 204 (2000) 181-224 
duda: ¿era sólo la "costumbre recibida", por antigua que fuese, o también la inmutable naturaleza de las cosas el principio que sustentaba el orden entre los sexos?:

«Yo respeto los límites que nos separan: y mi qüestión se reduce solamente a lo que pueden, no a lo que deben según están ordenadas las cosas por costumbre inmemorial, o por disposición de la naturalezaw (Le Moyne, 1798, III, 206).

"No disputo aquí contra el uso universal, ni pretendo cancelar con autoridad propia un reglamento inmemorial y una política tan antigua como la naturaleza. Aún es menos mi designio de publicar un bando, que llame a todas las mugeres a la guerra. Ellas deben estar a la disposición de la naturaleza, del derecho y de la costumbre recibida, y contentarse con la parte que las ha tocado en la economía y en el manejo de sus casas» (II, 185-186).

Como Le Moyne, muchos otros autores afirmaron que, si bien algunas mujeres habían brillado en ámbitos que no les eran propios, ello no facultaba al conjunto de su sexo para reclamar cambios en su situación. Así, los autores del Diario de Valencia añadieron a su alabanza de Isabel de Joya, española que había predicado públicamente en el siglo XVI, la cita de la carta de San Pablo a los Corintios (I Cor. XIX, 34-35) que prescribía a las mujeres silencio en la Iglesia, y con la que teólogos y moralistas solían justificar su exclusión del ministerio sacerdotal. La excepción, a juicio de los periodistas, no invalidaba una regla que Dios, la naturaleza y la ley concurrían en establecer: «Son incapaces pues del ministerio y orden Sacramental por derecho divino, positivo y natural, mas todo no impide el que alguna vez puedan conceder los Prelados a las mugeres el predicar» ${ }^{33}$.

Llevado al extremo, ese énfasis en la excepcionalidad podía subrayar, por oposición, la debilidad e incapacidad de las mujeres, reduciendo, como hiciera Nifo, las figuras de las damas ilustres a la condición de "prodigios increibles de este fragil sexo» (1755, "Assunto segundon). De esta postura a la de los autores misóginos no había más que un paso, que consistía en responder a las galerías de mujeres célebres con listas no menos nutridas de mujeres famosas por sus vicios, en restar importancia a sus hazañas, comparándolas desfavorablemente con las de héroes masculinos, de los que las damas no serían sino un pálido reflejo, o atribuyéndolas a la ayuda de los hombres, o bien en señalar que el reducido número de mujeres doctas probaba la incapacidad general de su sexo. Recursos todos ellos que pusieron en juego, por ejemplo, los adversarios de Feijoo, como Mañer, Manco de Olivares o Ballester, al atacar desde posturas

33 D.V. n. ${ }^{\circ} 105$ (16-IV-1798),p. 430. Una parte importante de la obra de Marie de Gournay se dedicaba, precisamente, a mostrar que la única razón de la exclusión femenina del sacerdocio era la costumbre y la tradición. 
misóginas la «Defensa de las mujeres» contenida en el discurso XVI del tomo I del Teatro crítico $0^{34}$.

A estos autores que hacían de las mujeres célebres una mera excepción a la incapacidad de su sexo, les respondió Josefa Amar señalando, con su característica habilidad argumentativa, que no eran las mismas las posibilidades que de estudiar y mostrar sus conocimientos tenían hombres y mujeres. A su juicio, estas desigualdades en el acceso a la educación explicaban por sí mismas que las mujeres sabias no proliferasen en igual medida que los sabios, como argüían los autores misóginos:

«si los hombres acreditan su capacidad por las obras que hacen, y los raciocinios que forman, siempre que haya mugeres que hagan otro tanto, no será temeridad igualarlos(...). Si los exemplos no son tan numerosos en éstas como en aquéllos, es claro que consiste en ser menos las que estudian, y menos las ocasiones que los hombres las permiten de probar sus talentos»35.

Entre misóginos y defensores de las mujeres se ponía así en juego todo un debate sobre el valor de la «excepción", sobre la pertinencia que los ejemplos de mujeres doctas, guerreras o gobernantes tenían para demostrar la «excelencia» o igualdad de los sexos. La historia presentada en forma de retablo de imágenes ilustres ofrecía así un campo para la polémica, y los mismos personajes se prestaban en ocasiones a usos opuestos, como Sansón, de quien unos hicieron prueba de la perversidad de las mujeres seductoras y otros de la lascivia de los hombres, en contraposición al control de sus deseos que ellas sabían ejercer: a fin de cuentas, como señalan Albistur y Armogathe, «siempre se encuentran mujeres célebres para probar lo que se desea demostrar» $(1977,177)$.

Las figuras de las mujeres sabias se utilizaron también con otra voluntad demostrativa distinta, para probar no tanto la igualdad de los sexos como el mérito de la cultura española. Sus efigies se integraron así en la literatura apologética dieciochesca que se ocupó de rebatir las críticas formuladas desde el extranjero sobre la aportación española a la cultura europea, empresa que tuvo sus episodios más conocidos en las respuestas al artículo sobre España publicado por Masson de Morvilliers en la Encyclopédie métbodique. Así, por ejemplo, los editores del Memorial literario, que dieron noticia de la investidura de $\mathbf{M}^{\mathbf{a}}{ }^{\mathrm{a}}$ Isidra Guzmán como doctora por la Universidad de Alcalá, aprovecharon la ocasión para reivindicar «las glorias de la nación Española» contra quienes «han procurado desacreditarla, ignorando unos y olvidando otros, que nuestra nación fue en todos tiempos fecunda, no solamente en ingenios elevados, en varones doc-

34 Por ejemplo, MANER, Salvador, Anti-Theatro crítico. Madrid, Juan Moya, 1729, p. 118 y Crisol Crítico-Theologico.Madrid, Bernardo Peralta, 1734, p. 178. MANCO DE OLIVARES, Laurencio, Contradefensa critica. Madrid, Francisco Sánchez Asensio, 1726, Pp. 14-16. BALLESTER Y DE LA TORRE, Manuel Mariano, Combate intelectual. Zaragoza, Joseph Fort, 1727, pp. 102-103.

35 Amar (1786; en NeGrín, Op. cit., p. 166). 


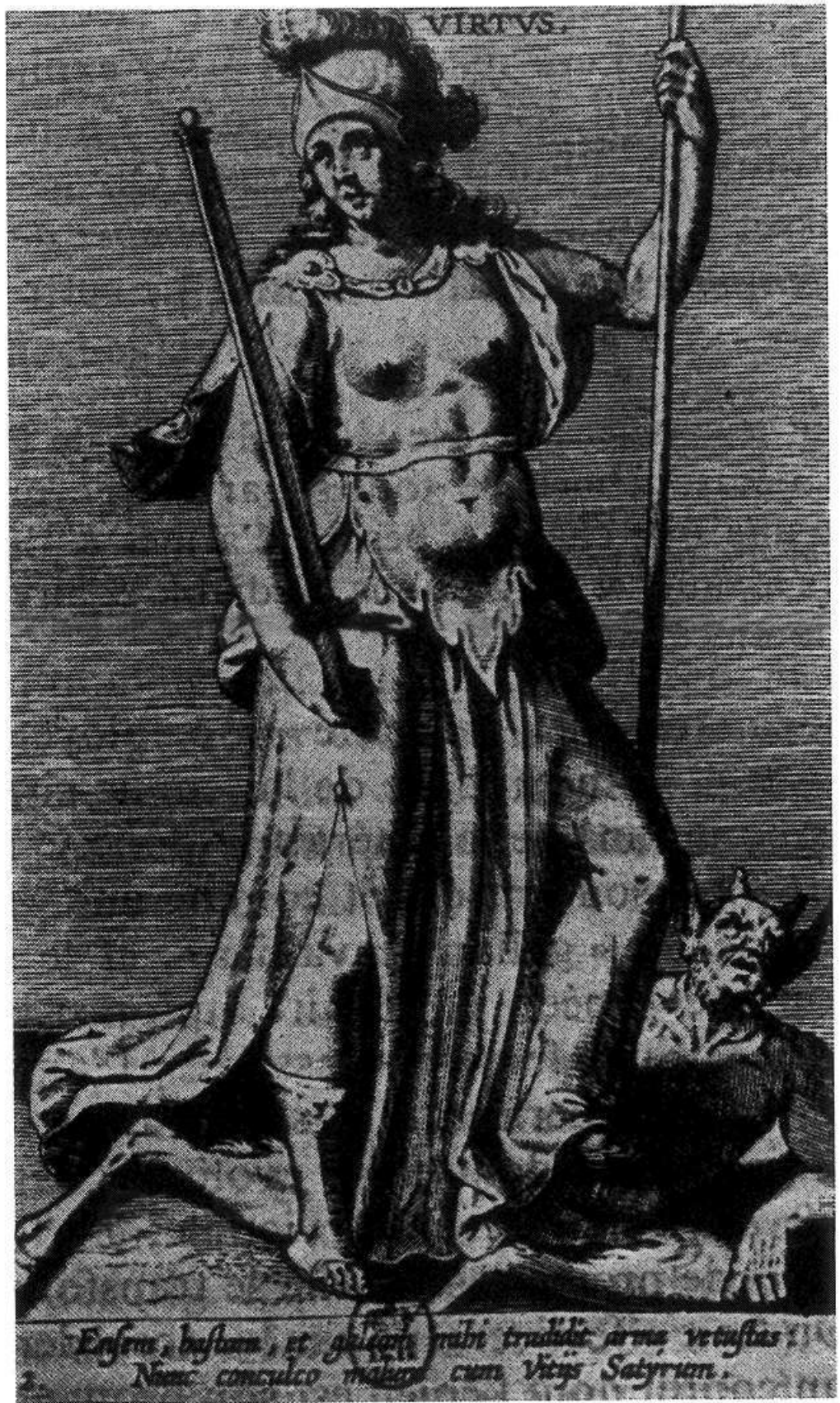

Phillipe Galle: «Virtus», en Prosopographia. Amberes, ca. 1590.

Hispania, LX/1, núm. 204 (2000) 181-224 
tos y escritores en todas ciencias y artes, mayormente en aquella edad en que las demás naciones estaban sepultadas en el profundo abismo de la ignorancia y que para salir de él necesitaron la mano de los Españoles, sino también que fue modelo de un sin número de mujeres ilustres en la literatura» (Memorial literario, junio 1785 , pp. 147 ss.).

Una de los más famosas aportaciones dieciochescas a la polémica sobre la contribución de España a la cultura europea, la del abate Lampillas en su Ensayo bistórico-apologético de la literatura española, desarrolló expresamente un elogio de las mujeres de letras españolas. Al refutar las acusaciones de los italianos Tiraboschi y Bettinelli, que imputaban a los escritores españoles la decadencia de la literatura latina, Lampillas hubo de contestar también a las páginas admirativas que aquéllos habían dedicado a las sabias italianas del Renacimiento ${ }^{36}$. Con ese fin, incluyó en su obra un apéndice sobre la literatura española del siglo XVI titulado "Las mugeres ilustres Españolas no cedieron á las Italianas en el cultivo de las letras, asi solidas como bellas", en el que se ofrecía una relación de damas célebres por su sabiduría, con especial referencia a Isabel la Católica y las mujeres cultas de su corte, como Beatriz Galindo, Luisa Sigea o Ana Cervatón. Si Lampillas afirmó sin reparos que «no es caso extraordinario en las mugeres Españolas verlas aplicadas al estudio laborioso de las letras, á las profundas especulaciones de la Filosofía, y aun á las Ciencias sublimes de la religión» (IV, 392), no era tanto por afirmar la igualdad de las mujeres como para pregonar el valor pasado, y por extensión presente, de las letras hispanas. No obstante, los ejemplos que recopiló podían interpretarse también en aquel sentido, y así lo entendió Josefa Amar, quien tradujo el Ensayo del italiano entre 1782 y 1784 y lo reeditó en 1789 con correciones y notas. En su prólogo, como hemos visto, aprovechó para llevar el agua a su molino, dirigiendo la atención de las lectoras hacia los méritos de las mujeres.

Los ejemplos históricos podían esgrimirse también con otros propósitos distintos a los anteriores. La propia Josefa Amar, al evocar en sus obras, tanto en el Discurso en defensa del talento de las mujeres como en el Discurso sobre la educación, a sabias españolas como Luisa Sigea, Ana Cervatón, Juana Contreras, Luisa de Padilla o Juliana Morell, pero también a reinas y guerreras, no solo pretendió demostrar las capacidades de las mujeres, sino propiciar su admisión en la Sociedad Económica Matritense. De ese modo, actualizó este clásico recurso argumental, haciendo de la arcaica galería de mujeres ilustres un arma en un debate que era inequívocamente ilustrado. Al mismo tiempo, esas figuras activas y resueltas podían servirle, identificándose con ellas, para fortalecer su propia confianza como escritora y para construir la imagen que de sí misma como mujer de letras ofreció a su público lector, una necesidad que experimentaron también otras escritoras de los siglos XV al XVII como las humanistas Christi-

36 Sobre la polémica de la cultura española y la literacura apologética del siglo XVIII puede consultarse MARías, Julián, La España posible en tiempos de Carlos 11 . Madrid, Planeta, 1988, pp. 32ss. 
ne de Pisan, Laura Ceretta o Catherine de Roches, Juana Inés de la Cruz, Marie de Gournay o Madeleine de Scudéry, amantes todas ellas de apoyarse en las mujeres ilustres del pasado.

\section{LAS AMBIGÜEDADES DE LA «MUJER FUERTE» COMO EJEMPLO DE VIDA.}

¿De qué modo podían compaginarse los brillantes retratos de princesas y nobles, sabias y guerreras, con la intención, que tan a menudo manifestaban los autores de catálogos, de proporcionar a sus lectoras enseñanzas morales para su vida cotidiana? ${ }^{37}$. Complejos, ciertamente, debieron ser los mecanismos, las estrategias de resignificación, por las cuales una obra como la de Le Moyne, poblada de figuras de reinas y damas armadas y punteada de episodios sangrientos (hasta el punto de merecer por parte de un estudioso actual, Pierre Darmon, el irónico calificativo de féminisme d'apocalypse), pudo ser recibida en estos términos por la prensa española, al ser traducirse en 1794, siglo y medio después de su publicación original:

«Es muy propia para instruir a las mugeres y de no poca utilidad para los hombres(...). Las mugeres la leerán con gusto y es de creer que los hombres no le tendrán menor al ver el orden y el método que la ilustran(...). Estas verán en ellas lo que deben hacer y cómo se han de portar cada una en su estado, y señaladamente en el de matrimonios 38 .

Fue precisamente la capacidad del catálogo para filtrar los ejemplos que contenía y forzar una lectura dirigida de los mismos lo que permitió a sus autores ofrecer esas poderosas figuras de mujeres ilustres a un público amplio y variado, pretendiendo que podían modelar sobre ellas sus propios comportamientos. Para ello hubieron de realizar fintas retóricas tanto más alambicadas cuanto mayor era la distancia que el paso del tiempo y las transformaciones culturales establecían entre los valores socialmente aceptados y los que transmitían las «mujeres fuertes».

Los modos en que autores, traductores y críticos utilizaron y aun forzaron los arquetipos para extraer de ellos mensajes morales válidos en diferentes épocas se ponen de relieve de forma muy interesante en la obra de Le Moyne tal como ésta circuló en su versión castellana de 1794. En ella se operaba una doble mediación que pretendía convertir las desafiantes figuras en modelos acep-

37 Así, afirmaba Alonso Alvarez de su catálogo: «Una obra sernejante no puede menos de ser utilísima en España. Las Damas sabrán hacer el verdadero aprecio de sí mismas, y hallarán en ella nuevos estimulos para aspirar á la heroicidad de sus mayores. Siendo estas instruidas, la ignorancia cederá el lugar a la sabiduría, y no se oiran tantas fábulas, y cuentos supersticiosas como preocupan los ánimos de los niños. AlvareZ, Op. cit., p. XXIl. También D.V. n. ${ }^{\circ} 179$ (29-VI-1798).

38 Darmon, Op. cit.p. 4. Reseña en Gacta de Madrid, n. ${ }^{\circ} 56$ (15-VII-1794), p. 843. 
tables para las lectoras. Por una parte, ya en la obra original el jesuita francés trató de guiar la lectura que a su juicio debía realizarse de sus ejemplos de "mujeres fuertes», señalando en todo momento la distancia existente entre su fuerza literaria de figuras excepcionales y su valor propiamente normativo. De otro lado, tanto el traductor como el editor de la versión castellana y los críticos que la comentaron en la prensa periódica debieron dar por buenas las interpretaciones del autor o quizá elaboraron sus propias lecturas morales de los ejemplos: en cualquier caso, admitieron la Galería de mugeres fuertes como una obra con validez didáctica para su propio tiempo, y como tal la ofrecieron a los lectores. Así, al presentar el libro en castellano, su editor, salvando la distancia entre la época del autor y la suya, afirmó que Le Moyne había escrito su texto «para que sirviese de imitación y de modelo a las mugeres de hoy; y para que éstas vieran por la obra lo que han sido sus antecesoras, lo que son ahora las presentes, y lo que pueden ser en lo venidero» («El Editor», I, VIII). Es muy probable que estos esfuerzos de canalización no resolvieran del todo la ambigüedad latente, y a nuestros ojos inquietante, que contenían todos los catálogos y muy en particular éste. No obstante, las lecturas que de las orgullosas, y con frecuencia sanguinarias, «mujeres fuertes» de Le Moyne pudieran hacer los lectores del siglo XVIII quedan veladas por la falta de testimonios sobre este último y más interesante eslabón de la cadena de transmisión cultural: el de la interpretación inherente al acto de la lectura.

En cualquier caso, la propia estructura de la obra de Le Moyne y los comentarios morales que glosan las hazañas de los personajes revelan la constante preocupación de su autor por salvar desniveles entre los ejemplos heroicos y las virtudes cristianas propuestas a las lectoras. Sistemática y ordenada, la Galería exponía los méritos de más de 40 mujeres en cuatro secciones recogidas en otros tantos volúmenes: las «fuertes judías», «romanas», «bárbaras» y «christianas». Cada personaje venía introducido por un bello grabado de empaque barroco que retrataba a la correspondiente «mujer fuerte», con gestos de solemnidad estatuaria, contra un fondo distante e impreciso. A continuación figuraban la historia de su gesta y un elogio de la misma, seguidos de una «reflexión moral» y una "qüestión moral" que tomaban la figura como pretexto para disertar en cada ocasión sobre un tema de conducta. Finalmente, ejemplos de mujeres célebres de la historia reciente ilustraban la moraleja. Si las primeras secciones enfocaban la individualidad del personaje, las últimas partían de ella para plantear preceptos generales de comportamiento y subrayar la lección moral por medio de casos más próximos al tiempo en que vivían los lectores.

Escritor en una época de la historia francesa, el siglo XVII, fuertemente marcada por la actuación política de las reinas regentes, María de Médicis y Ana de Austria, por las luchas políticas de facciones nobiliarias que alcanzaron su clímax en la Fronda, con participación de damas de la aristocracia como Mlle. de Longueville, la Grande Demoiselle, y por el influjo social y cultural que ejercieron salones como el célebre «hôtel de Rambouillet» presidido por la

Hispania, LX/1, núm. 204 (2000) 181-224 
marquesa del mismo título, Le Moyne manifestó, como muchos de sus contemporáneos, fascinación por la figura de la "mujer fuerte». Eclesiástico también, hubo de componer con ella un arquetipo conciliable con las virtudes cristianas, que tan poco se avenían con muchos de los ejemplos de reinas arrogantes o guerreras sanguinarias presentados en ese tipo de literatura. Su primer cuidado fue efectuar una reelaboración semántica de un término que podía sugerir comportamientos alejados del paradigma religioso de feminidad. Aunque la idea de «mujer fuerte» extraída de los Proverbios e inculcada por la moral eclesiástica correspondía a un ideal de domesticidad, piedad, trabajo y sumisión, los sangrientos hechos relatados por obras como la Galería de mugeres fuertes remitían más bien a otro tipo de cualidades. Por ello Le Moyne en su prólogo precisó que el título de su obra se refería a la fortaleza de ánimo, no al valor militar, lamentando que se valorasen las virtudes bélicas por encima de las domésticas:

«No es tan limitado este título que quiera parecer a algunos que no se conocen las virtudes sino por el quadro que hacen los Pintores; y no creen que hay otra fuerza que la que ellos ven con un morrión en la cabeza, y una columna en la espalda. Esta fuerza armada y robusta es solo subalterna de otra fuerza general que asiste a todas las virtudes; que de todas las grandes acciones es la que sostiene las buenas obras, y que dirige a todos los héroes en paz y en guerra. A esta fuerza atribuyen San Ambrosio y San Gregorio con Platón las victorias del espíritu sobre la carne, las de la virtud sobre la fortuna, y las de la honestidad sobre lo útil y agradable (...). Con efecto, esta fuerza conviene a las templadas y castas, a las fieles y constantes, a las modestas, contenidas y devotas; y acaso conviene más a ciertos presumidos y altaneros que se juzgan sostener los Estados, y creen que sus brazos son las columnas de los Imperios» (Le Moyne, I, XXIII-XIV).

En el tenso ambiente político en el que apareció la Galeries des femmes fortes en 1647, la Francia que vería a partir del año siguiente estallar en un conjunto de rebeliones, las Frondas, un huracán de descontento nobiliario, parlamentario, provincial y popular, resulta plausible ver en esa defensa realizada por Le Moyne de la fortaleza moral como digna alternativa al prestigio de las armas, un mensaje dirigido al conjunto de la nobleza díscola, con el fin de contribuir a pacificarla subrayando sus deberes al servicio de la monarquía. En ese mismo sentido cabe interpretar otro pasaje de la obra, lleno de censuras contra quienes menospreciaban a la reina regente, en aquel momento Ana de Austria, y osaban desafiar su autoridad, por considerar a las mujeres incapaces de ejercer el poder $^{39}$. Encarecer a la aristocracia reticente la necesidad de acatar la autoridad

39 En Francia, donde la Ley Sálica impedía desde finales de la Edad Media a las mujeres reinar por derecho propio, se sucedieron en los siglos XVI y XVII las regencias de Catalina de Médicis (cras la muerte de Entique In), María de Médicis (durance la minoría de Luis XIII) y Ana de Austria (a lo largo de la de Luis XIV). En Inglacerra, donde sí podían reinar en ausencia de heredero varón, el ascenso al trono de Isabel I, en un contexto de inestabilidad religiosa, fue acompañado de un vivo debate sobre la capacidad o incapacidad de las mujeres para reinar, iniciado por el calvinista escocés 
de la monarquía, con independencia del sexo de quien ejerciera el poder, constituyó un claro objetivo de su obra, junto con la defensa de la capacidad de las mujeres. Sin embargo, las distinciones que Le Moyne se vio obligado a hacer entre la «fuerza» moral y la guerrera no consiguen resolver la ambigüedad de su mensaje, toda vez que la mayor parte de sus «mujeres fuertes» exhiben ciertamente, más que ese valor morigerado, una virtud belicosa. El hecho de que su Galería se iniciara con una oda a la «mujer fuerte» de Salomón no elimina, antes, por el contrario, subraya esa disarmonía entre su mensaje moral explícito de conformidad cristiana y la agresividad de sus personajes.

La tensión, frecuente en la literatura de las «mujeres célebres», entre las acciones excepcionales y las normas de comportamiento propuestas a las lectoras se aprecia en las lecturas simbólicas y forzadas que extraían lecciones morales de las hazañas de las protagonistas. En estas obras, las heroínas clásicas, bíblicas o recientes, descritas de forma estereotipada, funcionan a modo de símbolos que los autores procuran descifrar a su público, guiando su lectura, más que como ejemplos que pudieran ser interpretados literalmente por las lectoras para imitarlos. Así, el mensaje subyacente en los retratos de «mujeres fuertes», por ejemplo en Le Moyne, era que al cambiar los personajes habían de transformarse también el escenario y el argumento de la acción moral, o, dicho de otro modo, que la lectura en clave normativa de esos hechos históricos o míticos era distinta de su evocación literaria. En lugar de pretender emular las acciones de las heroínas del pasado, ocupando el trono, empuñando la espada o bien tomando la pluma, sus lectoras, mujeres de su tiempo, debían conformarse con influir en la sociedad educando a sus hijos y preservando la moral familiar. Es decir, ejercer las «virtudes de su sexo» para procurar la utilidad social, en lugar de intentar imitar a los hombres o revivir gestas propias de tiempos más heroicos: las «mugeres belicosas», tan ensalzadas por los escritores, no debían eclipsar a "las pacíficas, que han hecho mucho bien en silencio y por las vías ordinarias de su sexo" (III, 83).

Reinterpretadas por el compilador, las acciones de estos vigorosos personajes perdían sus aspectos trágicos y teatrales para transmitir a las mujeres otras normas de conducta más propias de la vida cotidiana. Así, las sangrientas imágenes de Judit degollando a Holofernes o de Jahel matando a Sísara, se ofrecían como estímulo para que las mujeres entablasen lucha contra las pasiones: «No siempre tienen las mugeres Holofernes que vencer; pero sí tienen todos los días que combatir con el luxo, con la vanidad, con los placeres, y con todas las pasiones agradables y enfadosas. La memoria de esta muger heroyca las puede enseñar todos los ardides y exercicios de esta guerra, que aunque se hace a la sombra y sin efusión de sangre, no por ello dexa de ser laboriosa, y de executarse con espíritu y con firmeza de corazón» (I, 119). Pantea, esposa suicida

John Knox. SHEPHARD, Amanda, Gender and Authority in XVIth Century England. The Knox Debate. Keele, Ryburn/Keele University Press, 1994.

Hispenia, LX/1, núm. 204 (2000) 181-224 
por lealtad a su marido, debía enseñar a las casadas a tener a sus esposos un amor "fuerte y muy serio», "un amor y una caridad bien ordenada», alejados de todo exceso sensual (II, 40-49). Artemisa, de quien se decía que había bebido las cenizas de su esposo para no separarse jamás de él, representaba el dolor sin estridencias, la moderación, constancia y dignidad que debía presidir la vida de las viudas (II, 116). Mónima, asesinada por los celos infundados de su marido, enseñaba a las mujeres a evitar toda ocasión, aun la más inocente, de sospecha (II, 151-159).

Así pues, si bien la Galería de mugeres fuertes de Le Moyne, como todas las obras de su género, ponía de manifiesto la capacidad femenina para desempenar las mismas ocupaciones que los hombres y ostentar idénticas virtudes, las enseñanzas morales extraídas por el autor a partir de sus ejemplos tenían otro sentido bien distinto. Consistían en su mayor parte en elogios de las esposas pacientes, resignadas y castas, a quienes el jesuita predicaba una suerte de estoicismo cristiano que las ayudase a sobrellevar la sujeción (II, 151-152). De ese modo, si con una mano Le Moyne invitaba a las mujeres a ser conscientes de sus méritos y capacidades intelectuales, políticas y guerreras, en implícito elogio a las damas de la aristocracia, con la otra encarecía al común de su sexo paciencia y resignación ante la imposibilidad de ponerlos en práctica en la vida cotidiana. Él mismo fue consciente de esa paradoja y admitió implícitamente que su llamada al respeto del orden establecido no hacía sino salvar una brecha lógica: la que mediaba entre la igualdad o incluso "excelencia» de las mujeres en capacidades morales, intelectuales y políticas, a la luz del rosario de ejemplos aducidos, y su desigual posición en las relaciones de poder sociales, aun en los escalones más altos de la jerarquía estamental. Así lo reconoció al insinuar que la división de espacios sociales entre los sexos parecía violentar y constreñir sus aptitudes naturales:

"Yo no sé si el uso y la costumbre presente han hecho en esto alguna viokencia a la naturaleza: pero sí sé que tiempo ha habido en que ha estado más libre; y que la virtud de las mugeres, si estuviera menos sujeta que lo está en el día, serviría con utilidad en toda la República» (III, 75).

Moralista por encima de todo, Le Moyne se preocupó por ofrecer unas reglas de conducta que conciliaran las virtudes cristianas con las exigencias sociales propias de la vida en un medio aristocrático. En ese sentido, señaló con reiteración que las mujeres ilustres de sus ejemplos no quedaban exentas, en razón de su «excelencia» y alta alcurnia, de cultivar junto a sus capacidades guerreras o políticas la virtud por antonomasia de su sexo: la castidad. En ello refutó la obra renacentista y cortesana de Torcuato Tasso, que consideraba dispensadas a las damas ilustres de cumplir con severidad con esa exigencia y les otorgaba, al menos en el plano teórico y literario, alguna mayor libertad en el uso de sus cuerpos. Por el contrario, el jesuita Le Moyne se indignó por estas distinciones, que no cuadraban con su ideal de nobleza cristiana, y dedicó toda 
una sección de su obra a demostrar que «la castidad es propia del honor de las Heroynas y de las grandes Damas" ${ }^{40}$. No obstante, su idea de la castidad y el propio lenguaje con que la evocó diferían sustancialmente de la imagen sensible y contenida propia de la representación de la feminidad a finales del siglo XVIII, cuando su obra vio la luz en castellano, remitiendo en cambio a un ideal moral heroico de sabor barroco. La castidad es en su texto una virtud militante, simbolizada por «la rosa que está armada y pica»; su elogio de esta virtud, a partir de la hazaña de la "Judit francesa", que mató al hombre que pretendía violarla, bulle en resonancias marciales: «No conocen a fondo la castidad los que la ponen entre las virtudes pacíficas. Ninguna hay que esté más combatida, no que deba ser más guerrera, y a quien la fuerza y el valor sean más necesarios» (IV, 16-17); «hay combates domésticos, en donde la victoria es más difícil, y cuesta mucho más que en campañan (IV, 19-20) ${ }^{41}$. Una imagen que recuerda en parte la hagiografia cristiana de santas que sufrieron el martirio por defender su pureza, y en parte la representación más activa e incluso agresiva de la "excelencia" femenina forjada en ambientes aristocráticos y cortesanos de los siglos XV al XVII, de La cité des dames de Christine de Pisan al Discours sur la noblesse et préexcellence du sexe féminin de Cornelio Agrippa o Les femmes illustres ou les barangues bérö̈ques de Madeleine de Scudéry.

La obra de Le Moyne no es sino una ilustración particularmente interesante de las estrategias interpretativas desplegadas para transformar a las belicosas damas «ilustres» en ejemplos morales menos combativos y válidos para el resto de las mujeres. Otros autores adaptaron también a esos personajes para servirse de ellos con propósitos didácticos. Así, el desenlace trágico de muchos de los episodios relatados por los catálogos, y en especial la frecuente culminación suicida de los ejemplos heroicos de castidad y de amor conyugal, obligó a los compiladores a precisar que ellos no aprobaban, antes bien censuraban, tales actos: «En las mugeres que se mataron a sí mismas «-matizó Feijoo curándose en salud-», no se propone esta resolución como ejemplo de virtud, sino como exceso vicioso de la fortaleza, que es lo que basta para el intento ${ }^{42}$.

Para disuadir a las mujeres de la época de imitar a las heroínas célebres o míticas, era corriente también virilizar a éstas, situándolas así en un plano que

40 Atribuye la doctrina de Tasso a su amor por la princesa Leonor d'Este. «Esta novedad de mal exemplo (...) no debe prevalecer a la moral común: y no será bien hecho en las damas renunciar a la creencia de su sexo, y apartarse de la doctrina que la misma naturaleza las ha enseñado, por seguir la opinión de un interesado, de un poeta amoroso y pretendiente, que ha querido acomodar la filosofía a su pasión, y hacer progresos con sus nuevos dogmas" (III, 22).

41 "A muchos les parece que la castidad es una virtud blanda y de quierud, porque ordinariamente no tiene que hacer sino con las pasiones que se precian de dulces y agradables. Pero éscas son más diff́ciles de vencer que las ásperas y terribles; ya porque se desconfia menos de ellas, y los sentidos y la naturaleza están por su parte; ya porque su dulzura falaz, y sus artificios facilitan la puerta del corazón; y ya porque no habiendo determinada pasión que haga resistencia, sola la razón es la que debe combatir: y siendo ésta sola, y estando sin ayuda pelea floxamente, y sin vigorn (IV, 21-22).

42 FEIJOO (Teatro crítico, I, XVI, 352). También LE MOYNE, Op. cit., t. I, Pp. XXIX-XXX. 
las hacía inaccesibles. "Varoniles", como decían los editores del Diario de Valencia de Artemisa o de Mme. Guyon, estas mujeres habrían superado «los límites de su sexo", haciendo "salir de su propia esfera a las mugeres" ${ }^{43}$. De ese modo, se hacían acreedoras de la admiración que suscitaban las acciones meritorias de los hombres, pero al mismo tiempo de la censura por haber olvidado las cualidades que les eran innatas, según reprocharon Antoine-Léonard Thomas y Pueyo de San Pedro a la romana Julia, esposa de Septimio Severo. En elogio de la Judit bíblica diría Martín Cerecedo, autor de El Para Todos, un libro de conducta en los diferentes estados de la vida, que «ella no tuvo otra cosa de muger que el sexo» ${ }^{44}$. Estas expresiones ambivalentes resumen a la vez la fascinación y el rechazo que suscitaba en la imaginación literatia e iconográfica de la época la figura de la virago, la mujer «viril», de quien se admiraban su capacidad y valor al tiempo que se la reprobaba por su falta de feminidad. Reina por derecho propio en una época de justificación patriarcal del poder absoluto, soberana poderosa, rival de España y protestante por añadidura, Isabel de Inglaterra fue la virago por excelencia; de ese modo sus retratos posteriores, tanto elogiosos como denigrantes, reprodujeron la ambigüedad que entre el sexo de su «cuerpo privado" y el de su "cuerpo político» fomentó ella misma en vida ${ }^{45}$. "Unió las pequeñas vanidades de muger con los grandes sentimientos de los héroes, las ridiculeces de un sexo con las fatigas de otro, muchos defectos de un particular con todas las calidades de un Soberano perfectom, diría de ella el Correo de los Ciegos (n. ${ }^{\circ} 340,27-\mathrm{II}-1790$, pp. 2730-2732). En cambio, nada se dice en las relaciones dieciochescas consultadas sobre la más célebre de las mujeres travestidas de la España moderna, Catalina de Erauso, más conocida como la «monja alférez», quien, tras escapar de un convento dominico, sirvió como soldado en América y acabó obteniendo de Felipe IV la licencia para vestir de hombre junto con una pensión, ausencia explicable tal vez porque a la luz de la nueva

${ }^{43}$ Por ejemplo, Dido (n. ${ }^{\circ} 31,31$.VII-1797), las marquesa de $\alpha$ Bella-Isla» (n. ${ }^{\circ} 129$, 6-XI1797), María Pira (n. ${ }^{\circ} 143,20-X I-1797$; extraído de Boccaccio), Pisicracea (n. ${ }^{\circ} 72$, 13-HI-1798), Zenobia (n. ${ }^{\circ}$ 64, 5-III-1798), Mme. Guyon (n. ${ }^{\circ} 10,10$-VII-1797) o Artemisa (n. ${ }^{\circ} 111,19-\mathrm{X}-$ 1797). ThOMAs, Op. cit., pp. 14 y 27-28. La escritora inglesa Mary Astell captó con agudeza el desprecio implícito que mostraban esas observaciones: «Son los hombres quienes escriben la Historia, y raramente tienen la condescendencia de tomar en consideración lo bueno y grande que una mujer ha logrado; y si lo hacen es con esta sagaz observación: que las acciones de tales mujeres han superado los límites de su sexo» (citado en Pomata, Op. cit., p. 343, traducción nuestra).

44 Cerecedo ARDid y CANO, Martín, El Para Todos, en el qual se enseñan las leyes del bonor, de la bombria de bien, de la politica y cbristiandad a bombres y mugeres de todas clases, estados $y$ edades... Discurso IV; obligaciones de una muger como christiana. Madrid, viuda de Eliseo Sánchez, 1767.

45 Sobre el estilo político de Isabel I y el modo ambiguo en que ella misma se representó como reina, véase LEvin, Carole, The Heart and Stomach of a King: Elizabeth I and the Politics of Sex and Power. Philadelphia, University of Pennsylvania Press, 1994. Resulta interesante comprobar el carácter sexuado con que desde España se denigró la figura de esta reina enemiga, presentándola como «mujer diabólica, de temple casi varonil, "vergüenza de su sexo", según escribiría Ribadeneyra» (LÓPEZ-CORDÓN, Op. cit., p. 104). 
moral ilustrada, que llevó a censurar al personaje de la «mujer vestida de hombre» en el teatro, tal figura aparecía como indecorosa.

Así, los catálogos trataban en algunos casos a las mujeres «excepcionales» como si sus méritos las hubiesen convertido en hombres, subrayando de ese modo su distancia con respecto al conjunto de su sexo. En otros, por el contrario, se hacía hincapié en los aspectos «femeninos" de los personajes, la "honestidad" y pudor, domesticidad, "recato" y "gracias" no sólo de las figuras invocadas explícitamente en representación de tales cualidades, sino también de las mujeres sabias, gobernantes o guerreras ${ }^{46}$. El empeño por amoldar tales personajes a normas de comportamiento convencionales abocó a extremos como los de Le Moyne, que se esforzó por presentar a Débora o Judit asestando el golpe mortal a los enemigos del pueblo de Dios sin perder la modestia «femenina». Con un gusto muy barroco por el contraste y la combinación de opuestos, retrató en estos términos a la primera:

«su animosidad es muy decente y modesta, y de esta tierna fiereza que es como una flor de su cólera, y una tintura de zelo añadida a sus agrados naturales, se hace una tercera qualidad, y una mezcla de fuerza y dulzura, que hará un doble efecto en los enemigos, y les imprimirá al mismo tiempo el terror y la reverencian ${ }^{47}$.

Sin alcanzar tales extremos de virtuosismo en el uso de la paradoja, los retratos de algunas mujeres ilustres transmiten a lectores y lectoras una suerte de tranquilizadora estabilidad de las identidades genéricas, por la cual las mujeres excepcionales no solo no quedan exentas de cumplir con las normas sociales de comportamiento femenino, sino que las encarnan en su máximo grado, para instrucción del resto de las mujeres. Así pues, si la imaginación renacentista y barroca se mostró fascinada por la ambigüedad sexual, representada por las figuras andróginas del hermafrodita o la "virago", autores y lectores del siglo XVIII parecieron sentirse incómodos ante esas imágenes turbadoras, que suscitaban el vértigo de la fluidez de las identidades sexuales ${ }^{48}$. Antes que en la forma de la «virago», se prefirió, pues, en esta época representar a la mujer

16 Por ejemplo, en los elogios de Siti Maani (D.V., n. ${ }^{\circ}$ 94, 2-X-1797), Isotta Nogarola (n. ${ }^{\circ} 57$, 26-II-1798), Juana de Flandes (que aprendió las artes militares asin descuidarse del pudor de su sexo, sin agriar la dulzura y sin alterar las gracias” (LE MoYNE, Op. cit., II, 196), Lucrecia Helena o Luisa Sigea.

47 LE MOYNE, Op. cit., t. I, 31. De Judit afirma que «su esfuerzo es sin fiereza, y su denuedo se presenta modesto y sumiso" (I, 110). De Zenobia, que "tiene rodas las gracias de su sexo, y rodas las virtudes del nuestro" (III, 174).

48 Sobre la importancia de las figuras ambiguas (andróginos, mujeres viriles, hermafroditas) en la representación preilustrada de la diferencia sexual y su desaparición en el siglo XVIII, véase, para el caso español, Moreno Mengíbar, Andrés, y Vázquez García, Francisco, «Un solo sexo. Invención de la mono sexualidad y expulsión del hermafroditismo (España, siglos XVI-XIX)", Daimon. Revista de Filosofia, n. ${ }^{\circ} 11$ (1995). 
célebre como un ser que guardaba su feminidad a pesar de sus talentos «masculinos", como en el caso de la noble bolonesa retratada en el Diario de Valencia, que "reunió en sí las gracias de muger, y las ideas de hombre, haciendo quando hablaba, olvidar el mérito de su belleza» ${ }^{49}$.

\section{ACTUALIDAD DEL «PRODIGIO»: LA FIGURA DE LA MUJER SABIA.}

A lo largo de todo el siglo XVIII pervivieron, como hemos visto, entre los personajes femeninos que se consideraban dignos de evocación, modelos «arcaicos» de mujeres protagonistas de gestas militares o de sangrientas defensas de su honestidad. Fue, sin embargo, la figura de la mujer sabia la que mejor conectó con las preocupaciones de un siglo que debatió ampliamente acerca de los límites, objetivos, utilidad y modalidades de la educación femenina. Los catálogos de mujeres célebres venían ofreciendo desde sus orígenes una galería de sabias del pasado que arrancaba de figuras clásicas como Aspasia, Theano, Safo, Diotima o Hypathia, desgranaba algunos nombres de los primeros siglos cristianos e iba incorporando ejemplos más próximos a la realidad del momento. El Renacimiento añadió a esas figuras ilustres las imágenes de algunas mujeres que pasaron a constituir una presencia recurrente en los catálogos: italianas como Isotta Nogarola, Modesta di Pozzo, Casandra Fidele, Laura Ceretti, pero también inglesas, como Jane Grey, o las hijas de Thomas More, cuya erudición alabara Vives, son mencionadas con frecuencia en las obras españolas del siglo XVIII. Entre las francesas, el siglo XVII y el primer XVIII está bien representado en estos libros por personajes como Marie de Gournay, Madeleine de Scudéry o Mmes. Dacier, Lafayette y Sévigné. A su vez, para evocar a las mujeres de letras españolas la principal referencia erudita fue la Bibliotheca de Nicolás Antonio: de sus páginas quizá saltaron los nombres de Isabel de Joya, Ana de Cervatón, Juana Morell o Luisa Sigea a algunas de las muchas obras del XVIII que las mencionan. La omisión, por el contrario, de novelistas célebres del XVII como María de Zayas y Mariana de Carvajal se debió probablemente al descrédito que en el XVIII sufrían sus obras, como tantas otras de la literatura barroca, acusadas por los ilustrados de falta de decoro.

Como sucedía con las demás mujeres ilustres, también la mirada proyectada sobre las «sabias" era distinta de la que se vertía sobre los hombres doctos, pues en el caso de ellas su sexo interfería constantemente en las opiniones que suscitaba su actividad intelectual. Se tendió bien a virilizarlas o, por el contrario, a acentuar sus rasgos «femeninos». De ellas se alababa en ocasiones su penetración "varonil» y se destacaba su brillantez en campos del saber considerados masculinos, con palabras que traslucían cierta condescendencia hacia el conjunto de su sexo. Así, Lampillas, a cuyo juicio la mente femenina se enca-

19 D.V. n. ${ }^{\circ} 160$ (7-XII-1791, 270). 
minaba naturalmente hacia regiones menos áridas y más «amables» del saber, reconoció a algunas mujeres excepcionales el supremo valor de poseer una razón «masculina»:

«Si bien mucha parte del sexo femenino se compone de sentimientos de delicadeza; en que el corazon es la rueda maestra de su vida, y actividad, el gusto, y sentimiento los dos exes de su alma, y de su razon, con todo no falta un crecido numero de mugeres ilustres, que saben constituir por maestra del corazon la razon severa; y por exes de su alma el juicio, y la virtud, desmintiendo de este modo la opinion comun que les atribuye unicamente sentimientos de delicadeza» (1789, IV, 392).

En otros casos, los retratos de las mujeres sabias proporcionaban de ellas una imagen doméstica que insistía en su mérito por reunir talento y sanas costumbres, con el fin de librarlas del estigma moral que pesaba sobre las literatas. En la figura de Mme. Dacier (1654-1720), personaje habitual de los catálogos, se hizo particularmente manifiesta la tensión entre la tendencia a encerrar a las sabias en la estrecha horma de un modelo convencional de mujer y la tentación de presentarlas como hombres travestidos. De esta célebre erudita y helenista francesa, editora del Calímaco y traductora de la Ilíada y la Odisea, sus biógrafos destacaron, complacidos, que se hubiera negado a publicar sus comentarios sobre las Escrituras por considerar impropio de las mujeres opinar sobre tales temas: «Una muger debe leer y meditar la Escritura para arreglar su conducta sobre las doctrinas que nos ofrecen los libros santos, y que la Biblia nos enseña, pero debe guardar silencio, según el precepto de S. Pablon. Pero, al mismo tiempo, admiraron su audacia intelectual en la polémica con otro literato, La Motte, e interpretaron las posturas de ambos en ese debate como un reflejo invertido de las que por su sexo les hubieran correspondido. En opinión de sus contemporáneos y de quienes años más tarde siguieron glosando su figura, al adoptar Mme. Dacier un tono riguroso y firme, mientras que su contrincante redactaba en un estilo ligeto e intrascendente, ambos alteraron las convenciones que imponían a hombres y mujeres ciertas formas y estilos de escritura, de modo que eel discurso de La Motte parecía ser de una muger de espiritu, y el de Mme. Dacier de un bombre sabio" "50. Yuxtaponiendo en las semblanzas biográficas estos dos aspectos del personaje, la escritora modesta y la mujer de letras segura de sí misma, los autores de catálogos revelaron las tensiones que suscitaba en las mentalidades de la época la figura de la mujer sabia.

5o D.V. n. 24 (24-VII-1797),pp. 93-95. La retrataron también FEIJOO, Op. cit., cap. XVII, Thomas (quien la salva de la acusación de superficialidad que generaliza a las literatas francesas del XVII), LADVOCAT, Op. cit.,p. 278; D.V. (n. ${ }^{\circ} 39$, 8-II-1792, 555). Sobre esta autora y sobre la imagen que de ella se forjó entre sus contemporáneos, véase VAN DIJK, Suzanne, Traces des femmes. Présence feminine dans le joumalisme frangais du XVIIIeme siede. Amsterdam, Holland University Press, 1988, pp. 191 ss.

Hispania, LX/1, núm. 204 (2000) 181-224 
Era también frecuente y específico en los retratos de las mujeres de letras destacar aquellas figuras masculinas que las habían rodeado: padres que velaron por su educación, como los de Luisa Sigea o la propia Mme. Dacier, hombres ilustres (intelectuales, políticos, eclesiásticos) que se relacionaron con ellas y les mostraron admiración, como Justo Lipsio, Richelieu o Francisco de Sales a Marie de Gournay, o bien sabios que se negaron a reconocer su mérito, como en el caso de Oliva Sabuco de Nantes ${ }^{51}$. En mayor medida que en los elogios de varones célebres, los métitos de las literatas parecían, así, haber de confirmarse no sólo a partir de su propia obra, sino apelando a las opiniones de los sabios de su tiempo, que las autorizaban con sus elogios. A propósito de las actividades literarias de estas figuras femeninas se expresaban también con frecuencia inquietudes sobre los límites que cabía establecer a su ejercicio intelectual. Así, Le Moyne, tras considerar probada con argumentos y ejemplos la aptitud intelectual de las mujeres, las invitó, no obstante, a conformarse con «la filosofía práctica, moral» (III, 208), y Seixo, después de evocar a las mujeres predicadoras del pasado, recomendó a las mujeres de su tiempo que se limitaran a difundir la doctrina cristiana dentro del círculo de su hogar:

"Yo no hago su apología en esta parte, ni me empeño en promover su utilidad para el púlpito ni para el mando por una vocacion extraordinaria; pero sí entiendo que es una injusticia, y un objeto digno de correcion, el que hayan de vivir sepultadas, y en el concepto de que son incapaces para todo exercicio que no sea familiar» (...). «La doctrina inspirada á los domésticos por la voz y por el exemplo, en concepto de S. Juan Chrisóstomo, no merece menos elogios que el de la predicación del púlpito» (Seixo, 1801, 93 y 95).

El carácter que revistió el personaje de la mujeres de letras como anomalía más o menos tolerada, con mayor o menor fortuna domesticada y convertida en ejemplo moral, puede apreciarse, asimismo, en un último rasgo de los retratos. Común a muchos de ellos era el hecho de subrayar que las mujeres en cuestión habían enviudado jóvenes o rechazado el matrimonio para dedicarse al estudio, como Sor Juana Inés de la Cruz, de quien se decía que había entrado en el claustro, más que por vocación, en busca de independencia ${ }^{52}$. Así, la imagen que de las «mujeres sabias» se transmitía al público lector era la de personas que encauzaban sus vidas fuera de los cauces más habituales: excepciones sugerentes o inquietantes y siempre irreductibles a la normalización.

st Ejemplos de figuras paternas favorables son los de Mme. Dacier, Luisa Sigea, Tarquinia Molza o la marquesa de Lambert; respectivamente, D.V. n. ${ }^{\circ} 4$ (24-VII-1797), n. 3 (3-VII-1797), n. ${ }^{\circ} 29$ (29-1-1798) y 17 (17-VII-1797). El retrato de María de Gournay se encuentra en D.V (n. ${ }^{\circ}$ 122, 30-X-1797), el de Oliva Sabuco de Nantes en $n .{ }^{\circ} 73$ (11-IX-1707) y el de Gabriela Montemart en n. ${ }^{\circ} 80$ (19-1X-1797).

52 D.V. n. ${ }^{\circ} 66$ y 67 (4 y 5-IX-1797). 
Cabe destacar que las convenciones propias de los retratos de «mujeres ilustres" no se desplegaron exclusivamente en el género literario de los catálogos, sino que se utilizaron también para describir acontecimientos contemporáneos, como los exámenes públicos a los que en el siglo XVIII se sometieron algunas jóvenes nobles para demostrar sus talentos, supuestamente excepcionales. De ese modo, ese género tradicional se incorporaba a un ritual escénico y literario cuyos objetivos eran, en última instancia, políticos y propagandísticos: rendir tributo a sus poderosas familias y también al monarca, Carlos III, quien propició alguna de estas celebraciones. Al comparar a esas doncellas ilustres con las sabias y guerreras de la Antigüedad clásica y bíblica, humanistas españolas e italianas o escritoras francesas del siglo XVII, los ejemplos históricos se invocaban a mayor gloria de las homenajeadas, y la tradición se renovaba y vivificaba incorporando nuevas figuras al panteón de las «mujeres ilustres».

En 1785 una joven noble, M. ${ }^{2}$ Isidra Quintina de Guzmán, hija de los marqueses de Alegre, fue investida con gran solemnidad con el título de doctora y con una cátedra honoraria de la Universidad de Alcalá, tras ser sometida a un examen público «a presencia de todos los Doctores y Maestros del Claustro pleno, sus ilustres padres y un concurso numeroso y lúcido [sic] de más de 6.000 personas", acto al que siguieron diversas celebraciones y banquetes. Este acontecimiento social, del que dio cuenta un detallado relato publicado en el Memorial literario en junio de 1785 , fue sólo el ejemplo más fastuoso y célebre de una práctica que parece haber sido bastante usual en el siglo XVIIr: los exámenes públicos en los cuales jóvenes nobles demostraban su erudición y eran agasajadas ante lo más selecto de la sociedad y las autoridades locales, como el de M. ${ }^{a}$ Rosario Cepeda y Mayo, notable gaditana de 12 años, celebrado en 1768, la «función literaria» ofrecida en 1763 por los condes de Parcent en su palacio de Valencia para lucir las habilidades de sus hijos Cayetana y José, o el examen a que se sometió en la misma ciudad Pascuala Caro, hija de los marqueses de la Romana, en $1781^{53}$.

El hipotético mérito de esas jóvenes precoces quedaba, en tales circunstancias, oculto por la hojarasca retórica de los elogios y es muy difícil de apreciar tras el velo de descripciones altamente convencionales. Más que tratar de esclarecer el verdadero talento de esos personajes reales, nos interesa, por tanto, destacar las funciones sociales que cumplieron sus imágenes públicas, tal como quedaron consagradas y fueron difundidas por una amplia maquinaria propagandística que comprendía los elaborados rituales de lucimiento y exaltación y

53 Relación de los exercicios literarios que la Señora Doña Maria Rosario de Cepeda y Mayo...Cádiz, imprenta de D. Manuel Espinosa, 1768. Relación que bace un amigo a otro de la celebre liseraria función que en el día 7 de Abril del presente año 1763 buwo en la Ciudad de Valencia, en la Casa de los Excmos. Señores Condes de Parcent, executada por sus Excmos. Hijos D. Josepb y D. ${ }^{C}$ Cayetana de la Cerda y Cernecio. Valencia, Joseph Estevan Dolz, 1763. Examen a que se presentará D. ${ }^{2}$ Pasquala Caro y Sureda, bija de los señores marqueses de la Romana el dia [en blanco en el original] de abril de 1781. Valencia, Benito Monfort, 1781. 
los artículos periodísticos y opúsculos laudatorios que divulgaron esos actos. Ninguna de las homenajeadas tuvo con posterioridad una presencia notable en la vida cultural española: la intensa, desmesurada luz de los elogios ditirámbicos ilumina sus fugaces apariciones públicas para transmitir de ellas una imagen estereotipada ${ }^{54}$. La escenografía, el tono de las alabanzas, la espectacularidad de la exhibición y el tratamiento heroico de los personajes tenían el fulgor y la dignidad de los antiguos retratos de mujeres sabias y, como ellos, parecían «embalsamar» al personaje, envolviéndolo en un halo irreal. Figuras contemporáneas quedaban así incorporadas al panteón bien codificado de las «mujeres sabias", ofreciendo un contrapeso positivo al arquetipo de la «bachillera», que en la literatura satírica tradicional y también en el propio siglo XVIII ridiculizaba a las mujeres cultas. Lo que se reprochaba a las "bachilleras" era fundamentalmente que hiciesen gala de sus conocimientos, vulnerando con su ambición de notoriedad la modestia exigible a una mujer, y que se inmiscuyeran en materias definidas como masculinas. En cambio, en las «mujeres sabias» más célebres de la época se ensalzó precisamente su erudición, reconocida y pública, en saberes académicos poco habituales entre su sexo: lenguas clásicas y modernas, Geometría e Historia. Sin embargo, la oposición entre estos dos perfiles, la menospreciada "bachillera" y la mujer «ilustre en letras", era más aparente que real, pues esta última aparecía representada subrayando su carácter de «excepción" y limitando con ello sus posibilidades de actuar como ejemplo de conducta.

La escenografía desplegada en los actos públicos de exhibición de las jóvenes eruditas estaba impregnada de solemnidad. La exaltación de todas estas mujeres tuvo lugar en una ceremonia de aparato, abierta al público y en particular a un público selecto por su rango o dignidad de cargos. "Componiase el Congreso de las personas mas caracterizadas del Pueblo, ascendiendo su numero a mas de 300, con asistencia de los Generales, Gefes, Prelados, Maestros y demás Individuos, que forman los diversos cuetpos de esta Ilustre República», explicaba el narrador del examen de $\mathbf{M}^{2}{ }^{2}$ Rosario Cepeda en Cádiz, describiendo, como era habitual en estos relatos, los detalles de la tramoya y las actitudes de las protagonistas. En este caso concreto, el escenario estuvo presidido por el símbolo de la monarquía, un retrato del rey, y ornado por las representaciones

54 Salvo M. Rosario Cepeda, que fue socia de la Junta de Damas y su segunda secretaria sucediendo a la condesa de Montijo. M. ${ }^{\mathbf{a}}$ Isidra de la Cerda fue admitida a la Academia española y a las Sociedades Económicas Vascongada y Matritense, pero no se le conocen más escritos que los discursos gratulatorios que pronunció en tales ocasiones. Pascuala Caro, nacida en Palma de Mallorca en 1768, profesó religiosa y falleció en 1827, según Serrano Sanz, Manuel, Apuntes para una biblioteca de ecritoras españolas (desde el año 1409 al 1833). Madrid, Actas, 1975 (reimpresión del original de 1903), c. I, 521. Aguilar PiÑal, Francisco, Bibliografia de escritores del siglo XVIIl. Madrid, CSIC, 1981-1999 (t. II, ref. 1751) le atribuye un ilocalizable Ensayo de bistoria, fisica y matemática publicado en 1781 , lo que resulta poco verosímil, pues tendría entonces apenas 13 años; más probable es que sea una transcripción errónea del título del opúsculo de su examen (publicado en el mismo lugar, fecha e impresor y citado en nuestra anterior nota). 
del saber: mapas, libros y globos terráqueos. El marco de la Universidad dotó de empaque académico a otro examen, el de de M. ${ }^{a}$ Isidra de Guzmán, y la exhibición de Cayetana de la Cerda tuvo lugar en el entorno más mundano del palacio de sus padres. A medio camino entre la dignidad de las figuras clásicas, heroicas o aristocráticas y la "modestia» considerada consustancial a su condición de mujeres, a las protagonistas se las describía durante su actuación en términos que destacaban la "serenidad, entereza y apacibilidad", "compostura", "sosiego", "moderacion" y "candor de su sexo".

Estos actos constituían toda una ceremonia social que rendía pleitesía al poder y prestigio de esas familias, todas nobles o en vías de ennoblecimiento ${ }^{55}$. La exhibición erudita de las jóvenes permitía combinar dos tipos de elogios a la nobleza. De una parte, los tradicionales encomios de la antigüedad y elevación de su linaje (en el que destacaba, en el caso de $\mathbf{M}^{{ }^{2}}{ }^{2}$ Isidra de la Cerda, un ilustre antecedente: su abuela Luisa de Padilla, condesa de Paredes, mujer culta y escritora). De otro, las alabanzas, de corte más moderno, a la prudencia de unos padres ilustrados interesados en la educación de sus vástagos, como la marquesa de la Romana, a quien se presentaba como una "Ilustre Madre" que en la educación de sus hijos «no ha perdonado...tarea ni trabajo alguno, proporcionándoles todos aquellos medios que pudieran conducir al mejor éxito".

Los retratos muestran también una fascinación muy dieciochesca por el derroche de erudición infantil, como la que se hizo patente con motivo del examen público al que el pedagogo José Picornell sometió a su propio hijo en 1785 , a la edad de "tres años, seis meses y veinte y quatro días" "56. Los periódicos del siglo XVIII se hacían eco con cierta asiduidad de casos de precocidad que testimoniaban de una atracción, entre barroca y deudora del nuevo espíritu científico, por lo inusual y maravilloso ${ }^{57}$. En la galería de fenómenos insólitos de los que daba noticia la prensa (nacimientos múltiples o monstruosos, casos de longevidad excepcional o de deformaciones físicas), las niñas eruditas, cuyo sexo redoblaba el carácter extraordinatio de sus hazañas, parecían reputarse

"s M." Rosario Cepeda era hija de D. ${ }^{\mathbf{a}}$ Isabel Mayo y de D. Francisco de Cepeda y Guerrero, caballero de Calatrava, alguacil mayor de la Inquisición, regidor perpetuo de la ciudad de Cádiz, capitán de sus milicias y diputado de la Real Junta de Sanidad.

36 Examen publico, bistorico y geografico a que expone D. Juan Picornell y Gomila Socio de la Real Sociedad Económica de Madrid a ss bijo Juan Antonio Picornell y Obispo...Salamanca, Andrés García Rico, 1785 y Examen publico, bistorico y geográfico a que expone segunda vez D.Juan Picomell Gomila... a su bijo...Salamanca, Andrés García Rico, 1787.

37 Por ejemplo, en el Memorial literario de marzo de 1785 (pp. 378-379) se glosaban los méritos de una niña de cuatro años, tan adelantada que se le había permitido recibir la comunión a tan temprana edad. En la Gaceta de Madrid n. 36 (6-V-1800) se informaba sobre el examen superado por $\propto D .^{a}$ María Lizana, natural de Cadahalso, en la Villa de Pradon, de 11 años, a la que 11 meses aprendiendo latín habrían facultado, se decía, para sustituir en su cátedra a su maestro durante una enfermedad.

Hispania, LX/1, nún. 204 (2000) 181-224 
como un prodigio más de la naturaleza ${ }^{58}$. Como si tratasen de trasladar a la nobleza el modelo del examen al que fue sometida en 1785 la infanta Carlota Joaquina de Borbón, futura reina de Portugal, en religión, Geografía, gramática latina, Historia y lenguas extranjeras, los opúsculos hacían hincapié en la juventud de las homenajeadas y en la extraordinaria (e inverosímil) facilidad con que habrían adquirido sus saberes ${ }^{59}$. Así, de Pascuala Caro se decía a sus 12 años que «se ha impuesto en los ramos de erudicion que se ofrecen en este impreso" en "el breve tiempo de dos años», y Cayetana de la Cerda superaba, en palabras de su panegirista (más adulador, si cabe, que el anterior), a las más célebres sabias antiguas y modernas porque, a diferencia de ellas, había aprendido con pasmosa celeridad y sin esfuerzo $0^{60}$.

Tanto los elogios ditirámbicos y las referencias al alto linaje de las homenajeadas como el brillo de las ceremonias contribuían a producir un mismo efecto: un distanciamiento que subrayaba la excepcionalidad de los personajes. En una época en la que los perfiles de la educación femenina estaban en debate, reconocer el brillo de una excepción viviente, como aplaudir los talentos de las «mujeres ilustres» del pasado, no implicaba hacer extensible una educación «viril» a todas las mujeres de su condición ni, menos todavía, a las de un status social inferior. Así por ejemplo, el ayuntamiento de Cádiz, que en 1768 había celebrado los méritos de su gloria local, M. ${ }^{2}$ Rosario Cepeda, rechazó años más tarde la petición de una maestra francesa para abrir una escuela femenina, argumentando que el aprendizaje de esa lengua no era apropiado para las niñas ${ }^{6}$.

De todas estas celebraciones, ninguna fue tan espectacular como la investidura de M. ${ }^{2}$ Isidra Guzmán de la Cerda como doctora en Letras por la Universidad de Alcalá. La ceremonia de exhibición y homenaje tuvo en su caso características peculiares: el premio excepcional de un grado universitario y la intervención directa de Carlos III, quien se interesó por la joven y accedió a la petición de sus familiares. Con este gesto, el monarca afianzaba su imagen como rey ilustrado. Es posible que él o sus consejeros conociesen los casos de mujeres europeas como la astrónoma Laura Bassi, la helenista Clotilde Tambroni, la matemática Maria Gaetana Agnesi o la italianista Delle Donne en Bolonia, Maria Pelegrina Amoretti en Pavía, o Dorothea Leporin en Göttingen, que habían accedido a títulos e incluso impartido enseñanza universitaria. Todas

s8 VAN DIJK, Op. cit., pp. 193-197. Sobre la arracción por lo «prodigioso», «maravilloso" y «monstruoso» en el Antiguo Régimen, véanse PARK, Katherine, y DASTON, Lorraine, Wonders and the Order of Nature. Nueva York, Zone Books, 1998, y el catálogo de la exposicion: LAFUENTE, Antonio, y Moscoso, Javier, Monstruor $y$ senes imaginarios. Madrid, Biblioteca Nacional, 2000.

39 Gaceta de Madrid, n. ${ }^{\circ} 82$ (14-X-1785, pp. 669-670).

60 «Todas las que he mencionado/ se instruyeron en las Ciencias,/ mas después de algunos años/ precisos para aprenderlas./ Pero en Doña Cayetana/ fue buelo aquesta carrera/mal lo dixe, rapto fue,/ ni aun rapto fue, fue centella,/ que en breve tiernpo corrió/ espacio de muchas leguas" (Relación, 1763).

6r RomaN, Rafael, La enseñanza en Cádiz en el siglo XVII. Cádiz, Unicaja, 1991, p. 108. 
ellas gozaron de celebridad internacional y algunas aparecieron citadas en el artículo "Femme. Jurisprudence» de la Enciclopedia. Viajeros españoles del siglo XVIII llegaron a conocer personalmente a algunas de ellas, como Leandro Fernández de Moratín a Clotilde Tambroni, sobre la que dejó un comentario entre admirativo y condescendiente en su Viaje a Italia ${ }^{62}$.

Para los ilustrados españoles, exhibir algún ejemplo nacional servía para probar la «Ilustración» y «modernidad» del país, como exhumar las glorias femeninas del pasado era en la literatura apologética uno de los modos de «lavar el honor» de las letras españolas. Así, el autor del elogio de M. ${ }^{a}$ Isidra Guzmán de la Cerda la erigió en "heroína de las letras, no solo de este tiempo, sino de todos los siglos, de todas las Universidades y de todas las naciones". La presentó como una figura de enlace entre dos reinados gloriosos, el de los Reyes Católicos y el de Carlos III, fértiles ambos en mujeres sabias: en el primer caso, la propia reina Isabel y Beatriz Galindo, y en el segundo, según sostuvieron los editores del Memorial literario, muchas contemporáneas. La lista de éstas la encabezaba la infanta Carlota Joaquina, seguida por otros nombres, los de las traductoras Catalina de Caso y M. ${ }^{2}$ Antonia Fernanda de Tordesillas, la poetisa Mariana Alderete, Josefa Amar, M. ${ }^{a}$ Rosario Cepeda y dos autoras de epronósticos" o almanaques populares. Una relación que los autores del Memorial dejaron, con diplomacia, abierta de forma imprecisa a «muchas ilustres Señoras que conocemos y logran un mérito distinguido en las letras». Situada en el centro de todas las miradas, la imagen de $\mathbf{M}{ }^{2}$ Isidra Guzmán era así el espejo en el que se contemplaban el monarca ilustrado, su ilustre familia y con ella el conjunto de la alta nobleza, que gustaba en el siglo XVIII de dorar sus blasones con el brillo de la cultura y de representarse como una élite moderna y cosmopolita. Un espejo que les devolvía una visión halagadora de sí mismos e irradiaba al exterior la prueba de haber pasado el «examen de ilustración» que, a la vista de los ejemplos europeos, parecía requerir de una clase, un país y un gobernante una actitud magnánima hacia la educación femenina.

Si entre los ilustrados y el propio monarca parecía haber calado la idea de que, como afirmaran los editores del Memorial literario, «no hay nación culta que no pueda presentar un crecido número de mugetes estudiosas o aplicadas", era en buena medida porque algunas mujeres de letras europeas se hicieron célebres en nuestro país, a través de la traducción de sus obras o de las noticias

62 «El citado Aponte tenía una criada...que le asistía, hija de una pobre vieja, oyó muchas vezes las lecciones que daba su amo a los discípulos, mostró afición y el amo, que enseñara el griego a los perros de la calle, empezó a enseñársele a ella, en una palabra, la muchacha le ha aprendido en términos, que haze temblar al más estirado grecizante. Ha hecho varias odas en esta lengua, aplaudidas de quantos son capazes de juzgarlo, tiene excelente gusto en la poesía, y por las traducciones italianas que he visto de sus propias obras, creo que merece la grande estimación que se haze de su talento». Fernández de Mora'Tín, Leandro: Viage a Italia. Edición de Belén Tejerina. Madrid, Espasa Calpe, 1988, pp. 193-194.

Hispania, LX/1, núm. 204 (2000) 181-224 
que sobre ellas difundieron autores españoles ${ }^{63}$. Buen conocedor de la cultura francesa, Feijoo no ocultó su admiración por la amplia presencia de mujeres en la vida intelectual de aquel país: "Las Francesas sabias son muchíssimas: porque tienen más oportunidad en Francia, y creo que también más libertad, para estudiar las mugeres" (Teatro crítico, I, XVI, p. 380) ${ }^{64}$. Los elogios de algunas de las escritoras galas de los siglos XVII y XVIII, como la helenista Mme. Dacier, las novelistas Mme. de Lafayette y Mlle. de Scudéry, la matquesa de Lambert o Mme. de Sévigné, poblaron las páginas de los catálogos de mujeres ilustres y de las publicaciones periódicas. Traducidas, las obras pedagógicas y morales de Mmes. de Genlis, Le Prince de Beaumont, Lambert o Épinay y las novelas de Mmes. de Graffigny, Riccoboni, Gómez, Cottin o Mlle. de Scudéry circularon con éxito. Y además, testimonios como la Década epistolar sobre el estado de las letras en Francia del duque de Almodóvar (1781), que dedicó la última de sus cartas a las novelistas, mostraron a los lectores españoles que las autoras francesas aquí conocidas no eran sino parte de una floración más general $^{65}$. Josefa Amar, que conocía la obra de Almodóvar y que se mostró deseosa de destacar los méritos de las mujeres de letras, afirmó complacida en el prólogo de su Discurso sobre la educación física y moral de las mujeres (1790): «En Francia es grande el número de las que han florecido antiguamente y en el día florecen, y lo mismo en otros países" ${ }^{66}$. Con la moda de la literatura sentimental inglesa llegaron también las novelas traducidas de Miss Roche, Mrs. Bennet, Elizabeth Helme, Mrs. Radcliffe, Sophie Lee, Charlotte Lennox o Frances Sheridan. En Italia, Moratín conoció, como hemos visto, a la helenista Clotilde Tambroni y también a la periodista y traductora veneciana Elisabetta Caminer, a quien calificó de «literata insigne» "67. De la fama de las italianas Laura Bassi y Maria Gaetana Agnesi se hizo eco Lampillas, traducido por Josefa Amar, y ésta misma reprodujo en el prólogo a su Discurso sobre la educación el cálido elogio

6. Mem. Hit., abril 1786. Para apoyar la afirmación, remiten a los lectores a la consulta de cualquier diccionario de mujeres ilustres y, más específicamente, a la obra de Thornas o a la relación ofrecida por el propio periódico en junio de 1785 .

64 Feijoo elogiaba, entre otras literatas europeas, a Mme. Dacier, y citaba a Mme. de Lafayette y Mlle. de Scudéry en diversas ocasiones a lo largo del Teatro crítico.

os Almodóvar mencionó como predecesoras a Mmes. de Sévigné, La Fayetce, Dacier y Châtelet y comentó las obras de Mmes. Gómez, Genlis, Elie de Beaumont, Benoît, Puisieux, Riccoboni, De Laisse, Le Prince de Beaumont, Fanny de Beauharnais o Mlte. Fauque de la Cépède.

so AMAr, Josefa: Discurso sobre la educación física $y$ moral de las mujeres (1790). Edición de M. ${ }^{\mathrm{a}}$ Vicroria López-Cordón, Madrid, Cátedra, 1994, p. 70. En el mismo prólogo cita a Mme. du Boccage junco a ausoras de orras nacionalidades. "En Francia es largo el carálogo de literatas insignes, y cuando otras no hubiera, bastarían los nombres de la marquesa de Sevigné, de la condesa de Lafayette y de madame Dacier para acreditar que se han distinguido igualmente que sus paisanos insignes. En el día continúan varias señoras honrando su sexo con los escritos, como puede verse en la "década epistolar", de D. Francisco Maria de Silva" (Amar, 1786; en NEGRín, Op. cit, p. 166).

67 Fernández de Moratin, Op. cit., pp. 389-390. 
que el papa Benedicto XIV dedicó a la segunda, insigne matemática, con motivo de su acceso a la cátedra:

«con mucho gusto lo apruebo, y me alegro de que se ponga a las mugeres en estado de hacer lucir las ciencias y el ingenio. Os exhorto a que forméis ottas compañeras semejantes, a fin de acreditar que valeis por lo menos tanto como nosotros, si quereis aplicaros. El entendimiento se hace fútil si se emplea en niñerías, al paso que se eleva y engrandece si se acostumbra a la meditacion. Confieso que quando registro las bibliotecas, quisiera encontrar al lado de nuestros doctores mugeres apreciables, que hubiesen sabido engastar su ciencia en la modestia. De este modo podrían las mugeres habitar en los palacios de los papas, y yo tendria más ocasiones de traerlas a la memoria» 68 .

Asimismo, la muerte en 1787 de la estudiosa del derecho Maria Pelegrina Amoretti mereció la atención de la prensa española. El Diario de Madrid le dedicó un panegírico que extractaba su biografía y años más tarde el Semanario de Salamanca publicó un resumen de su libro sobre el derecho dotal tomano, "obra clásica por la erudición y crítica en materias legales», escrita con "fuerza y elegancia», en la que la autora defendía los principios del derecho justiniano, en opinión del redactor, porque era más favorable a las mujeres: «No es pues de extrañar que una de ellas, que se halla en estado de combatir con armas iguales con los hombres, reclame baxo tales auspicios los derechos de su sexo que se le quieren arrebatar» ${ }^{69}$. El mismo periódico reprodujo también un fragmento de la obra, en el que M. ${ }^{a}$ Pelegrina Amoretti reivindicaba el acceso de las mujeres a la escritura. Otra extranjera, la princesa Dashkova, o "princesa de Askoff", presidenta de la Academia de Ciencias rusa, fue ampliamente citada en España como ejemplo contemporáneo de «mujer ilustre» ${ }^{70}$.

A partir de estas referencias y del contacto con la cultura europea se hizo frecuente entre los escritores españoles expresar cierta admiración hacia las contribuciones que en algunos países realizaban las mujeres a las letras. En 1758 Nifo comenzó su Diario noticioso ponderando el desarrollo de las Ciencias y la Filosofia en Europa y subrayando el hecho de que aun las mujeres contribuyeran a él ( $\left.\mathrm{n} .^{\circ} 1,1-11-1758\right)$. Por su parte, uno de los censores de la traducción del Traité des études de Rollin a cargo de Catalina Caso (1755) afirmó que en su tiempo se veían «aparecer en los Theatros, y concurrencias de los Sabios,

68 Laura Bassi (1711 -1778) no llegó a imparcir docencia regular en la Universidad de Bolonia; "a causa de su sexo» dio sólo algunas lecciones solemnes y orras en su casa. Algunas de ellas se conservan, manuscritas o impresas. Publicó trabajos de Filosofía y de Física newroniana. Lampillas la cita (Op. cit., t. IV, p. 403). M. ${ }^{\mathbf{a}}$ Gaecana Agnesi (1718-1799), una buena conocedora de varias lenguas clásicas y modernas, se hizo célebre por su obra matemática Istituzione analitiche.

69 D.M n. 534 (16-XII-1787) y Sem. Sal., n. 290 (26-1-1796, pp. 81-82).

70 Josefa Amar apeló a ella como ilustre precedente de la participación de una mujer en una institución de sello oficial, con motivo del debate sobre la admisión de damas en la Matritense (en NeGRín, Op. cit., p. 166). También SeIXo, Op, cit., p. 128. 
y aun en las más famosas Universidades mugeres insignes, dotadas de excelentes ingenios", y se congratuló de que el trabajo de la traductora a quien le correspondía enjuiciar rivalizase con aquéllas en «juicio, buen gusto y propiedad»"1.

La figura que de la mujer sabia recrearon en el siglo XVIII estos elogios y ceremonias, no pretendía, como tampoco la efigie clásica de la "mujer ilustre», generar emulación, sino que subrayaba también su carácter excepcional. No obstante, los modos en que interpretaran esa figura los lectores y lectoras podían ser diversos y no siempre concordantes con la intención de los autores que la creaban. Así, las imágenes positivas de las mujeres cultas difundidas por los homenajes a las jóvenes cultas de la aristocracia o por los retratos de las escritoras europeas contribuyeron a transformar el lenguaje con el que se elogiaba públicamente a las damas ilustres. En efecto, en los panegíricos fúnebres la glosa de sus méritos intelectuales vino a sumarse a la alabanza de sus virtudes morales. Por ejemplo, la necrológica de la marquesa de Grimaldo publicada en el Memorial literario en mayo de 1786 subrayó su piedad tanto como el acierto con que había cultivado su intelecto y adquirido una amplia cultura, presentándola como ejemplo para su clase y para su sexo. El panegírico de la duquesa viuda de Arcos en 1784 destacó su «inclinación y pericia en las Artes» y el hecho de que hubiese sido admitida a la Real Academia de Bellas Artes de San Fernando y a la Academia Imperial de Artes de San Petersburgo, para concluir, en un brote de orgullo nacional: «No ha sido España escasa en Heroínas, pero en este siglo será esta Excelentísima Señora una de las más ilustres" (Memorial literario, enero 1784 , p. 82). De ese modo, estas imágenes brillantes de las mujeres de letras que circularon con cierta frecuencia en la prensa periódica del siglo XVIII pudieron inspirar, aunque no fuera ese su objetivo, en otras mujeres la ambición de emularlas, como quizá la incentivaran en Josefa Amar, amante de evocar en sus escritos a las mujeres sabias del pasado y el presente.

$$
* * * * *
$$

El catálogo de «mujeres ilustres», género clásico en la literatura europea de los siglos XV al XVIII, se revela así como un recurso versátil, sujeto a manipulaciones muy diversas y adaptable a la evolución de la sociedad, con pequeños pero significativos cambios que puntearon su historia, desde sus orígenes tenacentistas hasta su transformación burguesa en el siglo XIX. La poderosa, atractiva y desconcertante figura de la «mujer fuerte» fue, tal como interpretara Natalie Davis (1990), una «imagen polivalente» que los discursos y las prácticas sociales trataron de reconducir e interpretar en un sentido moralizante, pero cuya ambigüedad pudo proporcionar elementos para lecturas distintas. Fue en su origen una encarnación de la ética aristocrática y de su concepto de

7 Caso, Catalina, trad., Modo de estudiar las Bellas Letras para ilustrat el entendimiento y rectificar el corazón... Madrid, imprenta del Mercurio, 1755 (aprobaciones, sin paginar).

Hispania, LX/1, núm. 204 (2000) 181-224 
virtud, un símbolo que reconocía la preeminencia social de las damas a quienes se dedicaban las obras y al mismo tiempo un vehículo de expresión de mensajes sociales no dirigidos exclusivamente a las mujeres, que reflejaba en sus valores y sus formas de representación la hegemonía nobiliaria. Actuó así como emblema de los privilegios de una clase, expresados en forma de alabanza de la excepcionalidad de algunas mujeres con respecto a su sexo, como metáfora de la distancia insuperable entre privilegiados y no privilegiados. Al mismo tiempo, la evocación de sus méritos en letras, armas y gobierno constituyó un argumento retórico de primer orden en defensa de las capacidades femeninas en el contexto de la "querella».

A lo largo de los siglos, la figura literaria de la «mujer fuerte» despertó actitudes ambivalente, fascinadas y hostiles, ejemplificadas quizá mejor que en ningún otro caso en la mezcla de horror y atracción suscitada por el mito de las amazonas. Y ello porque la «mujer fuerte», gobernante, guerrera o sabia, evocaba el vértigo de la inversión de los roles sexuales y con él el de la quiebra completa del orden social, pero también sugería quizá las íntimas y contradictorias fantasías albergadas por hombres y mujeres de traspasar las fronteras genéricas establecidas.

Con la emergencia del modelo de domesticidad moderno y de su fundamento teórico, las teorías acerca de la «complementariedad» natural de los sexos, que definían a las mujeres en términos de sensibilidad, ternura, debilidad física y mental, la "mujer fuerte» se alejó cada vez más de los valores socialmente aceptados. No obstante, siguió gozando de cierta fortuna literaria y desempeñó nuevas funciones: interpretada de formas distintas según el contexto y, por así decirlo, «domesticada» y despojada de sus connotaciones más belicosas, sirvió a la apología de la cultura española, a la movilización patriótica en tiempos de guerra, a la adulación a las familias nobles o a la educación moral de las mujeres. Sin embargo, esos usos no agotaron jamás su poder de evocación. La figura, tan intimidante como atractiva, de la «mujer fuerte» fue un espejo en el que se miraron a lo largo de siglos las escritoras, para obtener de él una imagen que las legitimara a sus propios ojos o ante los del público, así como, más soterradamente, un fantasma en el que hombres y mujeres de los siglos modernos pudieron proyectar tanto sus temores como sus deseos ${ }^{72}$.

73 Véase al respecto KeLLY ("Early Feminism and the Querelle des Femmes», en Women, bistory and theory. The essays of Joan Kelly. Chicago, University of Chicago Press, 1984, así como Davis, Op. cit., y POMATA, Op. cit., pp. 349-350.

Hispania, LX/1, núm. 204 (2000) 181-224 